\title{
Forschungsbericht
}

Martin Hummel / Adrian Chircu / Jairo Javier García Sánchez / Benjamín García-Hernández / Stefan Koch / David Porcel Bueno / Inka Wissner

\section{Prepositional adverbials in the diachrony of Romance: a state of the art}

https://doi.org/10.1515/zrp-2019-0062

Abstract: The paper provides a state of the art in research on prepositional adverbials in Romance that combine a preposition with an adjective, e.g., Sp. en breve 'in short' (=PA-pattern). It therefore reviews the existing bibliography on Romance in general, Latin, Catalan, French, Italian, Portuguese, Romanian, and Spanish. The theoretical background is the hypothesis that the PA-pattern could have played a relevant role as a third way of forming adverbials in the diachrony of Romance, paralleling adverbial adjectives (e.g., breve used as an adverb: hablar breve) and derived adverbs (e.g., brevemente). The review confirms that the PA-pattern is marginal in (written) Latin but rises abruptly in early Romance, suggesting a "hidden" past in spoken Latin. This is corroborated by the fact that similar PA-patterns are used in all Romance languages. However, these insights have

Correspondence address: Prof. Dr. Martin Hummel, Karl-Franzens-Universität, Institut für Romanistik, Merangasse 70/III, A-8010 Graz, E-Mail: martin.hummel@uni-graz.at

Prof. Dr. Adrian Chircu, Universitatea "Babeş-Bolyai” din Cluj-Napoca, Departamentul de limba română şi lingvistică generală, Str. Horea, nr. 31, RO-400202 Cluj-Napoca,

E-Mail: adichircu@hotmail.com

Prof. Dr. Jairo Javier García Sánchez, Universidad de Alcalá, Departamento de Filología, Comunicación y Documentación, Colegio de San José de Caracciolos, C/ Trinidad, 5, E-28801 Alcalá de Henares, E-Mail: jairo.garcia@uah.es

Prof. Dr. Benjamín García-Hernández, Universidad Autónoma de Madrid, Departamento de Filologia Clásica, Ciudad Universitaria de Cantoblanco, C/Francisco Tomás y Valiente, 1, E-28049 Madrid, E-Mail: benjamin.garciahernandez@uam.es

Dr. Stefan Koch, Karl-Franzens-Universität, Institut für Romanistik, Merangasse 70/III, A-8010 Graz, E-Mail: Stefan.koch@uni-graz.at

Dr. David Porcel Bueno, Karl-Franzens-Universität, Institut für Romanistik, Merangasse 70/III, A-8010 Graz, E-Mail: david.porcel-bueno@uni-graz.at

Dr. Inka Wissner, Karl-Franzens-Universität, Institut für Romanistik, Merangasse 70/III, A-8010 Graz, E-Mail: inka.wissner@uni-graz.at

Ә Open Access. (c) 2019 Martin Hummel et al., published by DeGruyter. (c) BY This work is licensed under the Creative Commons Attribution-NonCommercial-NoDerivatives 4.0 License 
often to be deduced from marginal observations on the adverbials in use. As yet, research has not systematically studied the role of PA adverbials in the diachrony of Romance.

Keywords: Romance, Latin, adverb, adverbials, prepositional adverbials, adverbial locutions, Latin-Romance transition, analyticization, standardization

\section{Introduction}

The present paper deals with adverbials in Romance that follow the structural pattern "preposition + adjective," e.g., Sp. de seguro 'sure/for sure'. We will use the term PA-pattern for this structure, as well as PA adverbial to refer to single units. The interest in studying this pattern originates in Hummel (2014b, 698703), who observes that adverbial adjectives (e.g., Sp. mirar fijo), adverbs ending in -mente (e.g., mirar fijamente), and the PA-pattern (e.g., saber de fijo) frequently coexist in Spanish from the beginnings up to the 17th century:

(1) Adverbial adjective

(Type A)

continuo

extremo

fijo
Adverb in -mente

(Type B)

continuamente

extremamente

fijamente

\author{
PA-pattern \\ (Type C) \\ de continuo, a la continua \\ en extremo \\ de fijo, en fija, en fijo, de fijo, a la fija, \\ por fijo
}

The coexistence of these three adverbial types, also called Types $A, B, C$, is systematic inasmuch as Hummel (2014b) has detected 56 triplets of this type in the one million word corpus used for Company Company's Sintaxis histórica (2014). While the list of adverbs in -mente is considerably longer than the other lists, it appears that almost all adverbial adjectives go hand in hand with one or more PA adverbials that share the same stem. This points to a systematic productive relation between these variants (Types A and C). Given the historical priority of adverbial adjectives in the Indo-European tradition (Hummel 2013), it seems that the development "adverbial adjective > PA adverbial" is a path that diachronically appears in the Latin-Romance transition (see Section 2, below).

In a second step, Hummel (2019a; 2019b) has checked the morphological and/or semantic equivalents for the 56 PA adverbials in other Romance languages

Supported by: The paper is written in the framework of the project "The third way: Prepositional adverbials from Latin to Romance", supported by the Austrian Science Fund (FWF), project number P 30751-G30, directed by Martin Hummel at the Department of Romance, University of Graz. 
and varieties: Catalan, French, Friulian, Italian, Portuguese, Rumanian, Sardinian. The spot check provided overwhelming evidence for corresponding PA-patterns, e.g., in the case of 'dry':

(2) Cat. en sec, a seques, a les seques

Fr. en sec, à sec

Friul. a sec

It. in secco, a secco

Pt. em seco

Rom. în sec, pe sec

Sard. in siccu, a siccu

Sp. a secas, en seco

The fact that PA-patterns are likely to be or to have been a productive extension of, or an alternative to, adverbial adjectives in the whole domain of Romance supports the hypothesis that they have probably originated in Vulgar Latin, that is, the informal spoken Latin as opposed to written Latin, especially to Classical Latin (cf. García-Hernández 2018). As the examples in (1) show, many PA adverbials have disappeared in modern usage (e.g., a la continua, a la fija). This also holds for the series Fr. vrai, pour vrai, pour de vrai, pour le vrai, à vrai 'true'. However, some of these items have survived in modern Canadian French (Hummel 2019b).

These facts suggest two major scenarios for research. They allow submitting a first hypothesis according to which PA-patterns, which were almost inexistent in written Latin, have developed in the transition from Latin to Romance as a systematic analytic third way to create adverbials. They also allow a second hypothesis according to which PA-patterns have later been subject to a selection process during the elaboration of modern standardized languages.

The present paper aims at providing a state of the art in research on the PApattern in Latin and Romance. After some theoretical and terminological remarks in Section 1, the following sections deal with Latin (Jairo Javier García Sánchez, Benjamín García-Hernández), Romance in general (Martin Hummel), Catalan (David Porcel Bueno), French (Martin Hummel, Inka Wissner), Italian (Stefan Koch), Portuguese (David Porcel Bueno), Romanian (Adrian Chircu), Spanish (David Porcel Bueno).

1 We roughly gloss meanings in English for better orientation. This is problematic, insofar as many PA adverbials are polysemous, and even more so in the old language. Hence, the semantic diachrony of PA adverbials is a topic of its own that should be tackled by future research. 


\section{Theoretical aspects and terminology}

The heterogeneity of the word class of adverbs is a topic in the work on adverbs, to the point that its existence as a word class defined by positive criteria is often called into question. However, a higher degree of homogeneity can be found in subgroups. As far as PA adverbials are concerned, Hengeveld's typological approach provides interesting insights. According to the analysis of a sample of languages of the world characterized by maximal typological distance (Hengeveld 1992, 15, 20s., 62-72; Hengeveld/Rijkhoff/Siewierska 2004; Hengeveld/van Lier 2010; see critical aspects discussed by Croft 2001, 65-75), it is possible to distinguish three morphological types of adverbial modifiers. Languages such as English are "differentiated" since they separate adjectives and adverbs at the level of word class, e.g. a slow (adj.) man vs. The man runs slowly (adv.). Danish, Dutch, German, and Swedish (and Old English) are "flexible" since the unmarked form (German, Dutch) or a neuter form (Danish, Swedish, Old English) of the adjective are used for adverbial functions, that is, both adjectival and adverbial functions are assumed by the same word class, e.g., Ger. der schnelle (adj.) Mann vs. der Mann rennt schnell (adv.). This presupposes the similarity of adjectival and adverbial functions. "Rigid" languages use other word classes, e.g., verbs or nouns, for adverbial functions.

This analysis suffers from three biases. First of all, the typology overlooks the fact that languages are characterized by variation. In many Romance languages, the differentiated and the flexible system coexist and compete in diachrony (Hummel 2017), e.g., Fr. travailler dur (Type A), travailler durement (Type B), or Sp. trabajar duro, trabajar duramente, etc. The rigid type is rather marginal, but the structure "verb + adverbial noun" exists, e.g., Fr. boire nature, manger cochon, or Sp. pasarlo bomba. The competition of the three types turns out to be free if we take into account a second bias: word class obstinacy. This means that analyses that are restricted to word classes exclude syntax-based alternatives such as Fr. $\grave{a}$ la dure or Sp. a duras penas (Type C). In other words, Romance uses prepositions in order to create adverbials with nouns or verbs (Fr. à reculons). Now, it is clear that series such as Fr. dur, durement, avec dureté are widespread in Romance. Consequently, a functional approach to adverbials must not be restricted to word class. The third bias concerns the split of the word class of adverbs. In fact, the three types, differentiated, flexible, and rigid, only coexist in the field of manner adverbials, with extensions to quantity and intensity. Adverbs of time or place are excluded. However, the division into subgroups seems to be useful, above all because the very word class of adverbs entails a major bias: it is created by negative criteria, by units that do not belong to other classes. Hence, the definition of subgroups with positive criteria is a progression. However, seen from the perspective 
of this paper, crucial similarities between manner adverbials and time or place adverbs persist, insofar as prepositional phrases are highly frequent amongst both manner adverbs and adverbs of time or space, including frequent univerbation: Fr. dedans, aujourd'hui, etc. This means that the subdivision of adverbs into serveral groups is useful, but there is no best theoretical approach in absolute terms. In this sense, Hengeveld's analysis is simply an adequate theoretical background for studies on PA-patterns, if the analysis bears in mind its biases.

The Types A,B,C (see (1)) have then to be discussed in terms of productivity, equivalence, semantic and functional differentiation, lexicalization, and diachronic loss. Current approaches run the risk of being one-sided. An important tendency views Type $C$ as adverbial locutions to be analyzed in dictionary entries. In this case, their productivity and competition with the Types A and B, as well as diachronic aspects, are absent or marginal. Obviously, this depends on the definition of the term locution. If adequately defined, it could be used. However, in linguistic disciplines such as morphology or syntax, a locution tends to be considered as a lexicalist term, whereas terms such as prepositional phrase/group (PP) refer to the underlying productive structure. However, the term PP is not specific enough for the purpose of this paper, since it involves more than adverbials, e.g., Fr. avoir pour but 'to aim at', lit. 'to have for goal'. This means that a more specific term is needed to refer to adverbials with the structure "preposition + X". For this reason, we have chosen the terms PX-pattern and PX adverbial. We thereby specify that we deal with particular patterns of PP. PA-patterns are a subpattern of PX, as are PN-patterns (Sp. a duras penas), PV-patterns (Fr. à reculons), etc. Further subdivisions may also be made, e.g., Sp. a las claras, a las buenas, a las malas as instances of a specific PA subpattern (see more examples in (1)).

More details in this regard may be found in Hummel (2019a; 2019b), who discusses several theoretical aspects of PA-patterns: PA-patterns as a systematic analytic alternative to Types A and B in the Latin-Romance tradition (in the process of "analyticization"), their usage in the oral vs. written tradition, their role in processes of language elaboration ("Sprachausbau") and, especially, standardization, as well as their emergence through colloquialization of adverbs in the speech of educated people.

\section{Latin (Jairo Javier García Sánchez \& Benjamín García-Hernández)}

Although adverbials combining preposition and adjective exist in Latin from the first literary texts and increase in frequency throughout history, we could not find 
any specific study on this topic. Some interest in PA adverbials as folk expressions arose in manuals on Latin morphology, syntax and history, as well as in studies on adverbs, preverbs, prepositions, and style.

Hofmann/Szantyr's Syntax (1972, 223, §116, Zus. b) cites ex aduerso 'in front of', e contrario 'conversely, to the contrary', and in directum 'in direct line' in the chapter on prepositions. The first two of these are said to develop to exaduersum and econtra, with exaduersum functioning as a preposition since Cicero. By contrast, in directum, which seems to be a calque from Gr. kóx'ỏ $\rho \theta$ óv (cf. TLL V 1, 1255, 1ss.), assumes prepositional functions only as late as in Romance (Old Fr. endroit). For their part, Kühner/Holzweissig (1986 [1912], 1018, §226, 11) insert a short paragraph on the composition of preposition and adjective in their chapter on adverbs, where they mention four of them: in-cassum 'in vain', de-nuo (de nouo) 'again', im-primis 'in the first place', and cum-primis 'in first line'. They further mention the combinations of preposition plus noun (obuiam 'on the way'), plus pronoun (antehac 'until now'), and plus adverb (deinde 'after, afterwards').

The chapter on adverbs in the first volume of Bassols' Syntax (1967, 177-185) only mentions the well-known PA adverbial denuo, amongst locutions combining prepositions and nominals (admodum 'to a large extent', adfatim 'sufficient, enough'). In the Romance appendix at the end of this volume we find only one PA, en seguida, following PN adverbials (encima, arriba). In the chapter on prepositions (1967, 225-263), Bassols draws attention to the increase in prepositions combined with adverbs in Vulgar Latin, especially since the Roman Imperial Period (§227), as well as the formation of adverbials with adjectival participles: ex aduerso 'in front of', ex improuiso 'suddenly, unawares’ (§266).

In his Storia della lingua di Roma, Devoto (1987 [1940], 180) observes in Lucretius' poetry the use of folk expressions and of archaisms in the tradition of Ennius (239-169 B.C.). He highlights de subito 'suddenly' (2, 265; 3, 243), where the preposition reinforces the concept already included by subito, according to a schema that will be successful in Late Latin and in Romance. In line with this, Risicato (1950, 55), who analyzes the "spoken" language in Ennius, cites three instances of de repente 'suddenly' and one of de subito, both of which later agglutinate. These are also the only two PA adverbials that we could find in Väänänen's manual on Vulgar Latin (1995 [1967], §203). It is noteworthy that the older manual by Grandgent (1963 [1907], §47) also quotes ad sero 'in the evening', ad subito 'suddenly', de medio 'from the middle (out), out of the way'. The latter is used by Petronius $(38,12)$ in the proverb ubi semel res inclinata est, amici de medio 'as soon as business weakens, friends pull away'.

At the end of the pages dedicated to the adverb subito in the Itinerarium Egeriae (4th century A.D.), Löfstedt (1911, 168-170) mentions the rise of ad subito (adsubito) as a new variant of older de subito (desubito). On page 176, he notes the 
adversative use of denuo meaning autem 'but, however'. Still more interesting are Säuborg's (1941, 20-30, 332-335) observations on de... parte (ab... parte, ex... parte): de dextera (/ sinistra) parte 'on the right/left side'. Once deleted, the noun, preposition, and adjective tend to adverbialize (cf. Fr. à droite): habens de sinistra et dextra 'to have on the left and on the right side' (Grom. 314, 15); inflexus (Nilus) a sinistra ad Aegyptum descendit 'after turning left, (the Nile) descends towards Egypt' (Cosmogr. 93, 15).

To conclude, the data that can be found in manuals and linguistic studies is very limited, and, in general, repetitive. However, the number and variety of constructions is superior to what the bibliography suggests. Suffice it to look at the entry dealing with the preposition de in Lodge's Lexicon Plautinum (1924) where the following PA adverbials are documented: de meo (sumptu) 'at my expense', de tuo 'at your [sg.] expense', de uostro 'at your [pl.] expense', de alieno 'at the expense of third parties', de pleno 'in full, squarely', de compecto 'okay'. And if we take a 1100-year leap in time, we find in Lange (1966, 82s.) the medieval expression in prono (> improno 'downwards'), from which derives impronare 'to go down', the new adverbial ad impronum 'downward', and the toponymical variants Emproo, Amprom, Emproa, Amproa. Hence, while there are good reasons to assume the use of PA adverbials in Latin, their complete documentation and thorough analysis is still, to the best of our knowledge, a desideratum for future research.

\section{Romance (Martin Hummel)}

It is interesting to see that the landmark study founding Romance linguistics, Friedrich Diez's Grammatik der romanischen Sprachen, provides an original analysis possibly the most original - of the adverb regarding the topic of this paper (Diez 1882, 737-742). For Diez, Romance expresses "by far the most adverbials with nouns". Constructions with the Latin ablatives modo or mente are just variants of this tendency, e.g., lento modo 'in a slow way' or sola mente 'simply, only'. Consequently, in Diez' analysis, the paragraph on mente is not as prominent as it is in modern grammars. He starts by describing deverbal or denominal adverbials such as It. a tastone, in ginocchioni, a cavalconi, adding corresponding groups in other Romance languages. In the first example, the evaluative suffix -one transforms the verb tastare 'to fumble' into a nominoid form. He observes that most members of this pattern may appear with or without preposition (It. braconi, carpone, ginocchione, etc.). This supports Hummel's (2019a; 2019b) hypothesis that PA adverbials are variants of preexisting adverbials. However, Diez feels that the use of the preposition "expresses the original relation". It is not clear if this is meant in terms 
of historical anteriority or in terms of underlying semantics. At any rate, for Diez the relation seems to be "PX adverbial > short(ened) adverbial" rather than the other way round. Diez explicitly explains OldSp. and OldPt. certas with the ellipsis of a preposition. Possibly, the genetic relation assumed by Diez is more likely to be true in the case of nouns and verbs, while adverbial adjectives may more easily precede PA adverbials. In fact, adverbial adjectives were common in Latin, whereas PA adverbials appeared later. Diez also insists on the idea of "nominal reinforcement", an idea that is commonplace in studies on PX-patterns in Romanian (see Section 8). Again, this might rather concern the use of evaluative suffixes only and not, e.g., PA adverbials such as Sp. a las claras or de seguro.

Diez' analysis provides an elegant and simple explanation for a series of phenomena that have remained unexplained in all linguistic studies and grammars up to the present. Many studies assume a tacit dummy nominal in PA-patterns such as Sp. a las buenas, a las malas, a las claras or Fr. à la légère, à la douce, à la dure, but if it is true that the most important means of building adverbials in Romance was using a noun, there are good reasons to argue that there was a general tendency to convert other word classes into nominals or "nominoids" when they were used for adverbial functions. Consequently, the famous and still unexplained "adverbial $s$ ", such as in Fr. certes, could simply be another technique of reinforcing its nominal appearance or "nominality". It is noteworthy that Chircu (2007, 67-75; see Section 8) describes the use of Rom. -ul in de-a lungul, de-a latul, de-a largul, pe de-a-ntregul, etc., as a "false article", that is, a technique of reinforcing nominality. The phenomenon is commonplace in Romance, if we take into account that the Romanian enclitic article -ul corresponds to free morphemes in other Romance languages and varieties; thus, the following series follows an analogous pattern: Cat. a la llarga, Fr. le long de, à la longue, It. alla larga, Pt. ao longo de, Rom. de-a lungul, Sp. a lo largo de, al largo de, a la larga. In the old language and sometimes in present day regional varieties, one also observes patterns such as Fr. pour le vrai, pour un petit (Section 5). In dialects of Portuguese and Spanish we find adverbials such as una poca de agua / uma pouca de água, without preposition, but still nominalized (cf., e.g., Bourciez 1967 [1910], 456).

It comes as no surprise that Diez fills pages with PX-patterns. Somehow surprising, however, is that Diez also becomes a victim of his own genius. In his view, the most important adverbial contractions concern adverbs of time or place with the structure "Preposition + Adverb" (PAdv-pattern), e.g., starting from Lat. de-super, ex-ante, in-ante, per-inde. These adverbials do not follow the principle of nominality. Hengeveld's split of the class of adverbs offers a solution. As shown in Section 2, there are good typological reasons to separate adverbs into two groups: adverbs of time and place, on the one hand, and adverbs of mannerquantity-intensity, on the other. The principle of nominality only holds for the 
second, even if both groups overlap. In French, the Types A,B,C coexist for the adverb of place-time-intensity in Fr. à la longue, longuement, en dire long. In sum, the nominality principle seems to have been relevant in the domain of manner adverbials, extensions included, which is the domain we deal with when discussing the PA-patterns. However, the use of prepositions is a technique that spans adverbs of time and place. It thereby provides a good point for discussing the inner, or at least underlying, coherence of the word class of adverbs in Romance from a diachronic perspective.

Although manuals of Romance linguistics or of single Romance languages including the perspective of Romance usually mention the PX-pattern, this group of patterns plays a marginal role: cf. Meyer-Lübke (1972 [1899]) in Section 5; Darmesteter (1967 [1893], 80-82); Bourciez (1967 [1910], 258-261); Zauner (1926, 81), who already uses the term "Redensarten" (locutions), suggesting lexicalization; Lausberg (1972), who mentions PX-patterns in a few lines (§703) at the end of a chapter on "periphrastic adverbials" mainly dealing with -mente (\$§700-703); Tagliavini (1959); and Elcock (1960). PX adverbials are widely documented in Chircu (2008), albeit subordinated to adverbial adjectives and adverbs in -mente. It should be mentioned also that the survey on "Sentence adverbs in the languages of Europe” (Ramat/Ricca 1998) does not consider the PX-pattern, although there is a clear diachronic tendency to use them as sentence adverbs, e.g., in It. di sicuro, Sp, por cierto, Fr. au juste (cf. Hummel 2019a; 2019b).

All this clearly shows that the linguists' perception of adverbs in Romance has changed since Diez. In the end, it appears that the fundamental article of our project, "The third way" (Hummel 2019a; 2019b), should probably have been named "The first way", at least in two senses. PA-patterns are "first in the specific diachrony of Romance, that is, the first genuinely Romance way" and they are also "first regarding importance in the origins, that is, the main means of forming adverbs, at least in spoken language", if we focus on the language transition from spoken Latin to spoken Romance. The term "The third way" bears all the biases of modern linguistics' canonical view on grammatical categories, suggesting a "paraphrastic", secondary rank of PX adverbials. In sum, reading linguistic texts written in former centuries thus sometimes makes us aware of our own presentday biases.

\section{Catalan (David Porcel Bueno)}

The texts written in Old Catalan have already documented numerous PX-patterns. Griera (1931, 97s.) offers a list of some of the most common ones, among which we also find PA-patterns: al devall, a derredor, de dret, en gir, al present, a estonades, 
de veres, al tort i al dret, de debó, a la biorxa, a betzeps, a benvista, per be, en cerca, en cert, de cor, a despit, etc. Furthermore, Moll (1952, 204), when he speaks about the most frequent adverbs of quantity in the history of Catalan, points out that adverbial locutions are usually formed with the preposition $a$ plus a nominal element, such as a balquena, a la baldor, a l'uf, a cabassos, a cacarrells, etc.

Some very productive PX-patterns in Old Catalan have also been analyzed, as is the case for the locutions de part (Bruguera 1981), en funció de (Vilaró 1987) or other PXP-pattern (Casanova 1984). Perera i Parramon (1986; 1987) studied some characteristic PX-patterns of Old Catalan from the 15th century, while Badia i Margarit $(1947$; 1951) investigated the "pronominalo-adverbiales" complements in the Ibero-Romance languages from a comparative point of view (all of which stem from the Latin adverbs ibi and inde).

With regard to modern Catalan, Badia i Margarit (1962, 11-85) makes a first classification of the most important PX-patterns of the Catalan spoken in Barcelona. Therefore, within the chapter about the adverbs of place, he dedicates one section to the most used adverbial locutions of place (al dins, al defora, a mig aire, a la dreta, al capdamunt, al capdavall, al voltant, a l'entorn, etc.), and does the same with the adverbial locutions of time (de seguida, de/a vegades, de tant en tant, de quan en quan, en va, etc.), with those of order (d'antuvi, de bell antuvi, de bell començ, etc.), and with those of manner, of which he offers more than a hundred examples, many of them PA-patterns (ib., 25-27).

Badia i Margarit also points out that some adverbs and adverbial locutions (almost always of place or time) become prepositional locutions by adding the preposition de, forming a PXP-pattern: al defora de, al voltant de, al darrera de, al damunt de, etc. (ib., 68s.). As in the case of adverbial locutions of manner, the author offers an extensive list of Catalan prepositional locutions (ib., 84s.).

More recently, Lopez/Morant $(2008,1810)$ refer to adverbial locutions as "expressions idiomàtiques de composició i ordre fixos" which in many cases are analysed as variants of a -ment form (a very debatable point) and which are made of a preposition and a noun. Although we can find PA-patterns among the examples (en breu, a l'engròs, d'amagat, etc.), they do not mention the fact that these locutions can be formed on the basis of an adjective. In the chapter dedicated to prepositions, Sancho Cremades (2008, 1785-1790) only provides a list of the most frequent prepositional locutions (most of them PXP-patterns): a part de, a banda de, de dret a, en direcció a, per mor de, per mitjà de, per via de, a base de, etc.

The information on Catalan prepositional locutions that we can find in Sancho Cremades (1994) is much more detailed. In different parts of this paper the author refers to the "sintagmes preposicionals matisadors", among which we can find PA-patterns with clear discourse functions (ib., 64-67): en concret, al contrari, en especial, en general, en definitiva. These examples are part of a long list of 
PX-patterns (per això, per tant, a més, d'altra banda, en cavi, en realitat, etc.). On the other hand, Sancho Cremades (1995, 95-99) makes a clear distinction between prepositions and prepositional locutions, pointing out that the semantic correspondence between these two must be understood in a referential sense:

“Totes dues poden fer referencia a una mateixa realitat, però en suposen una conceptualització distinta. La preposició és vehicle només d'una relació; La perífrasi focalitza l'aspecte nominal al tems que una relació" (ib., 99).

We can also find partial references to PX-patterns in Cabré i Monné (1980), Camprubí (1984), Palau (1986), and, from a comparative perspective, in Palet (1987).

Phraseological research has also dealt with the study of PX-patterns, both from a synchronic and diachronic perspective (Fuster/Sánchez 2012; 2014). Lorente Casafont (2008, 831-888) has made a systematic study on locutions in Catalan, distinguishing grammatical locutions (including prepositional locutions with PXP-pattern), on the one hand, from lexical locutions (including adverbial locutions with PX-pattern), on the other. Regarding the prepositional locutions, he points out that it is usual to insert an article (al bo de, al llarg de, al voltant de, etc.) or idiomatic adjectival modifiers (al bell mig, a gran desgrat de, a excepció exclusiva de, en referència només $a$, per mitjà solament de, a cópia només de, etc.) (ib., 848). For their part, adverbial locutions are defined as syntagmatic structures formed of classes of words generally different from the adverb, which can modify both verbs and sentences, but not adjectives (this is what differentiates them from the "adverbis complexos") (ib., 866). This author also mentions some paradigmatic PA-patterns: a les males, a las bones, del cert, de bo de bo, a bastament, a bastança, etc. (ib., 867s.).

As usual, it is the lexical repertoires that collect the largest number of PApatterns in Catalan. Such is the case with Martí Mestre's historical dictionaries (2006; 2017), which allow us to retrieve the PA adverbials of Catalan that have not survived in the modern language (cf. Vernet 1999, Ginebra/Navarro 2000, Martines 2007, and the dictionary of phraseological units of modern Catalan (Espinal 2004), among others).

\section{French (Martin Hummel \& Inka Wissner)}

French has both a huge fund of texts available for diachronic research, even before 1500 , and a long and rich tradition in grammaticography and lexicography. Studies on French should therefore provide a large array of data and analyses on PA adverbials. Yet, this is not the case.

Modern grammars pay little attention to PX adverbials in general, and PA adverbials in particular. The terms used foreground lexicalization: "locutions pré- 
positives” (e.g., Brunot 1905-1979, vol.1, 215), “locutions prépositionnelles” (e.g., Riegel/Pellat/Rioul 2013, 369s.), "locutions adverbiales” (e.g., Wagner/Pinchon 1987, 382). The term suggested by Le Goffic (1993, 443), “groupe prépositionnel”, favors in principle a productive syntax-based analysis, but the author insists on restricted usage:

“Groupe prépositionnel adjectival: à nouveau. La construction d'une préposition avec un adjectif est restreinte à quelques emplois: - emplois figés (quasi-adverbiaux): à nouveau, de nouveau, en general,...”

If PX adverbials are mentioned in a grammar, they are prototypically seen as lexicalized combinations of a preposition with a noun. It seems that in modern French the adjective needs a noun to be admitted in a productive series of adverbials. In line with this, Bally (1965 [1932], §395) observes that the following PNpatterns are productively used to compensate for the restricted use of some adverbs ending in -ment: d'un œil sévère, d'un ton sévère, d'une manière sévère, d'une façon sévère. In fact, lexicalized metaphorical transpositions such as naturellement 'obviously' or curieusement 'strangely' (the same as Engl. naturally, curiously) may force speakers to select de manière / façon naturelle, avec curiosité, etc., in order to reactivate the original meaning. According to Bally, there are less restrictions operating on these patterns than on adverbs in -ment. Since PN-patterns are used to replace missing synonyms in -ment, grammars generally refer to them as "paraphrases". In the series mentioned by Bally, the patterns " $d$ 'un œil + adjective" and "d'un ton + adjective", as well as a long list of similar adverbials, are almost restricted to literary style, while the patterns "de façon / manière + adjective" are typical of standard.

French grammars also mention PX-patterns that combine a preposition with an adverb of place or time or another preposition. Most of these have undergone early univerbation: devant, derrière, avant, après, auprès, parmi, là-dedans, etc. Many adverbs of time and place were created in this way. The fact that PX-patterns build the nuclear group of these functions explains why grammars list these lexicalized univerbations. Some grammars only refer to this group (e.g., Wartburg/Zumthor 1989, 376). The fact that many PAdv- and PP-patterns underwent early univerbation suggests their nuclear role in diachrony. In other words, PApatterns may have followed pioneering PAdv- and PP-patterns (and PN-patterns). According to Ortiz Ciscomani (2017), the Old Spanish core of the PA-pattern had directional semantics (e.g., a derechas), which was later extended to manner semantics (e.g., a solas, a secas).

The patterns used in the conceptual domains of place and time do not compete with the PA-pattern, which is mainly used for modification in terms of manner, quantity, intensity and discourse functions (e.g., epistemic pour de vrai, cf. 
Féron 2007 and Hummel 2019a; 2019b). While sincèrement, de façon sincère, and avec sincérité are direct and mutual competitors, adverbs of time or place belong to separate functional domains. This is also the reason why Hengeveld (1992) and other authors (see Section 1) have suggested dividing the heterogeneous word class of adverbs along this line. Adverbs of time or place will therefore not be discussed further in this section. It is noteworthy, however, that Fagard has thoroughly studied the relation between simple prepositions and complex prepositions in synchrony and diachrony, e.g., dans in contrast to au sein de, au cour de, au milieu de, or Lat. ante > Fr. devant/avant (Fagard 2009, 2012a, 2012b; Fagard/ Mardale 2012; Fagard/Sarda 2014). If we formulate the research question in analogy to our project on PA-patterns, the relevant series would have to share the same stem, for instance, dans, dedans, là-dedans. This is the case in Fagard's (2012a) case study on the successors of Lat. ante, where he also insists on the pan-Romanic dynamics of the development.

More so than other Romance languages (except Romanian), grammars of the French language dedicate chapters to adverbial adjectives such as couper court 'to cut short', courir vite 'to run fast'. If Hummel (2019a; 2019b) is right in claiming that PA-patterns are "natural" developments of adverbial adjectives, e.g., vite and à la vite, then we should expect to find them in these sections. This is not the case, not even in the five volumes of Togeby's (1982-1985) Grammaire française. PA-patterns are at best separately classified either as adverbials (paraphrases, locutions) or as prepositional groups. Finally, in the French grammars' chapters on the adverb, PX-patterns always play a minor role because grammars only classify the different functions of the canonical adverb in -mente, together with univerbations of PP-patterns: devant, dedans, alors, etc. The former are located in the "manner" chapter, the latter in the chapters on adverbs of place, time, etc.

Exceptions to this radical marginalization can be found in grammars that are less guided by standardized conceptions of the educated but simply try to classify and analyze all data that can be found. Damourette/Pichon (1911-1933, §505) dedicate one paragraph to the PA-pattern, where they distinguish two types: one with article, the other without article (à la française vs. en douce). Regarding the latter, they criticize the rationalistic obsession of reducing linguistic phenomena to underlying constructions:

"Nous ne nous rallions pas à l'opinion des grammairiens qui prétendent que dans en douce, il n'a y pas l'adjectif doux, mais qu'on a affaire à une apocope de en douceur".

They thus mention another reason why PA-patterns might have been less important for some authors: They are not considered as being original forms from a genetic point of view. 
The "longest" series of PA-patterns in a grammar of modern French, which is in fact a short list, is provided by Grevisse/Goosse $(2016, \S \S 965,966)$, and includes some participles: à découvert, à nouveau, à présent, à jeun, de nouveau, d'ordinaire, en général, en particulier, par exprès, tout de bon, au dépourvu, en définitive, d'affilée, d'emblée, de plus belle (16th century: de plus beau), à la dérobée, à l'anglaise, à l'européenne, à l'ancienne, à la légère, à l'étourdie, à la douce, à l'aveuglette, à la sauvette, à la franquette, en douce, tout de bon, pour de bon, pour de vrai, pour de faux, pour de sûr, de long en large.

During the elaboration of modern standard French, roughly from the 16 th to the 19th century, PX-patterns were not criticized in the metalinguistic discourse but rather seen as a useful periphrastic alternative for "true adverbs" (Hummel 2018). This obviously includes a status of secondariness, in line with the dogma of word class being primary to syntax. The term generally used, "paraphrase”, provides evidence for the idea of PX-patterns "replacing" word classes. Some PX-patterns enter Palsgrave's list in Lesclarcissement de la langue françoyse (1530). We have counted 15 different units, with only three of them following the PA-pattern: tirer $\grave{a}$ bon, regarder en louchet, tout à plein et à découverte. The fact that some 140 adverbs in -ment figure in this first grammar of French, which was written for teaching good French, shows that these had already become canonical, while the three PA adverbials provide evidence for the fact that many of the units that were usual in the 16th century have disappeared in modern standard French.

In his Histoire de la langue française, Ferdinand Brunot (1905-1979, vol. 2, 373-378), observes indeed that a large number of old adverbs were on their way to becoming archaic in the 16th century. This means that the adverbial system underwent a general restructuration process. While Brunot mentions PX-patterns in the first two volumes of his history, from the origins to the end of the 16th century, they are lacking in the third volume, "La formation de la langue classique (1600-1660)". According to Brunot, two major tendencies operated on paraphrases from the second half of the 16th century onwards. The most important of these was selection for the sake of purism, "bon usage", "génie de la langue", and "clarté et logique" (rationalism). In other words, not all alternatives or variants were likely to survive in modern standard French. Brunot $(1922,598)$ puts it as follows: "A la suite de Malherbe, on apprit à se contenter de la pauvreté, et même de la cultiver”. The whole work of Malherbe (1555-1628) and Vaugelas (15851650), as well as that of many other "remarqueurs", was dedicated to separating the wheat from the chaff. The following citation provides an example of the selection process in a series of PN adverbials that share the same stem: 
"Fin, ne se met point seul pour enfin: à la fin, à la parfin, est vulgaire: en fin: en fin finale, antique: sur la fin, finalement: finablement antique \& hors d'usage (Oudin 1972 [1632], 278 and 1972 [1640], 275).

Obviously, most native speakers did not read and follow such recommendations; nevertheless, most members of the series in this quote have disappeared or no longer belong to modern standard French. In line with this, Féron (2001) analyzes the diachronic selection process in her case study on Fr. pour certain/sûr/ vérité/voir/vrai (cf. also Hummel 2019b). Negative selection also affected the pleonastic adverbials Fr. en enhaut and en embas (Brunot 1905-1979, vol. 4:2, 747, compare Diémoz 2016). The reinsertion of the preposition shows both lexicalization (enhaut, embas) and ongoing productivity (addition of the free morpheme en).

The metalinguistic discourse in the historical context of enlightenment upgraded "paraphrases" for two reasons. In the first place, they were analyzed as the original, genetic basis of adverbs, providing an early "generative" approach, in particular in Arnauld/Lancelot's Grammaire générale et raisonnée (1973 [1660; 1676], 76):

“Le desir que les hommes ont d'abreger le discours, est ce qui a donné lieu aux Adverbes. Car la plupart de ces particules ne sont que pour signifier en un seul mot, ce qu'on ne pourroit marquer que par une preposition \& un nom: comme sapienter, sagement; pour cum sapientia, avec sagesse: hodie, pour in hoc die, aujourd'huy".

In the second place, paraphrases were upgraded in virtue of the principles of clarté et logique:

“Et c'est pourquoy dans les Langues vulgaires, la plupart de ces Adverbes s'expliquent d'ordinaire plus élegamment par le nom avec la préposition: ainsi on dira plûtost avec sagesse, avec prudence, avec orgueil, avec moderation, que sagement, prudemment, orgueilleusement, moderement, quoy qu'en Latin au contraire il soit d'ordinaire plus élégant de se servir des Adverbes" (ib., 77).

This quote shows that the generative analysis was based on PN-patterns. Pierre de La Touche's L'Art de bien parler françois (1973 [1696], 30) recommends replacing légèrement armés by a PA adverbial in armés à la lègère, but this is an exception. As shown above, the PX adverbials used as paraphrases in modern French follow the PN-pattern: de façon (manière) naturelle, avec curiosité, d'un œil (d'un ton, d'un air) sévère, sur un ton sévère, d'un pas lent, le pas lent, les yeux fermés.

This short summary of the normative metalinguistic discourse in France is important insofar as it has been widely received in other Romance languages. French played an important role as a model for the "elaboration" (Kloss 1967; 
1978) of modern Romance in general (Hummel 2013; 2018), and to a lesser degree of Germanic, in particular English (Hummel 2014a). The data provides evidence for a normative preference and the prototypicality of the PN-pattern. PA-patterns are marginal in this discourse. While modern French productively uses PN-patterns as "paraphrases", PA-patterns form a limited set of lexicalized units, at least in standard. However, Hummel (2019b) provides an example of the productive use of en réel in informal French: "car en réel elles préfèrent les bad boys gros cons". Hence, it seems that register plays a crucial role.

Interestingly, the restrictions of modern standard French do not apply to Old French. A spot check in the Altfranzösisches Wörterbuch (Tobler/Lommatzsch 1925-2002) - which is a dictionary, not a grammar! - shows that PA-patterns were indeed abundantly used. The spot check provides the following variants:

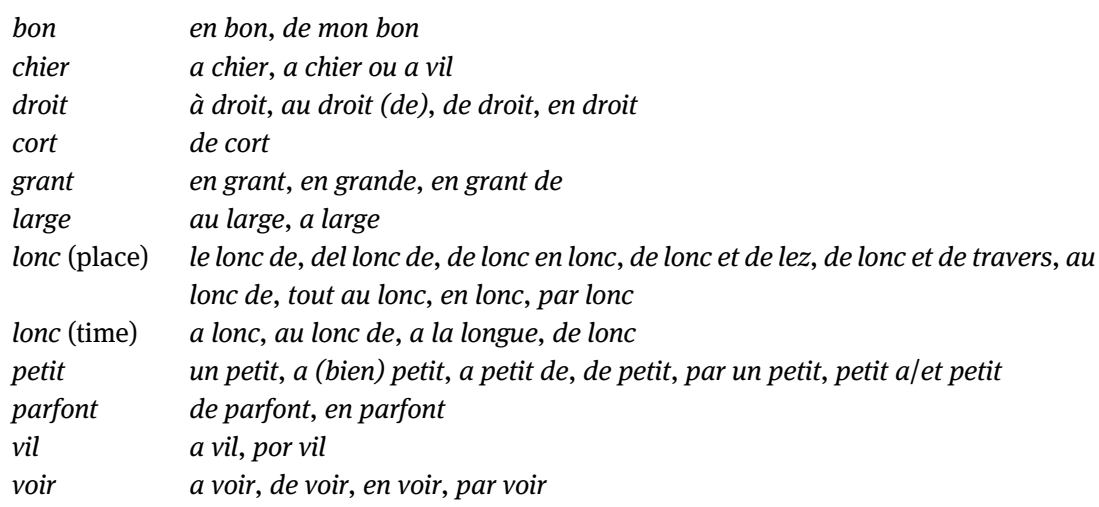

This is not the place to point out the semantic differentiations provided by each of the series. For our purpose, the important facts are: (i) PA adverbials were abundantly used in Old French, (ii) almost all of them have disappeared in modern standard French, (iii) nominalization is frequent, (iv) local and directional concepts produce the longest series. The latter possibly supports the hypothesis of the nuclear role played by adverbials of time or place (see above), eventually followed by quantitative concepts.

Strictly speaking, the empirical spot check in Tobler/Lommatzsch should not be a part of a bibliographic survey. But the survey itself would oblige us to state that PA adverbials play a marginal, unproductive role in French, if any. The spot check shows that this is due to a lack of interest in research on this issue. PA adverbials clearly are an issue for diachronic grammar. The vision of PA-patterns as lexicalized locutions represents our present-day view, which is biased by modern standard French. Despite the availability of the excellent documentation provided by Tobler/Lommatzsch, grammars and studies on Old French do not ana- 
lyze PA-patterns, probably because they see the past with the eyes of modernity, e.g., by the prioritization of word class and, secondarily, that of PN-patterns. Rheinfelder's Altfranzösische Grammatik, for example, does not mention PX-patterns in his chapter on adverbs (1967, 70-73). Even though they are mentioned in his chapter on prepositions (ib., 316-346), the PA-pattern is lacking. In addition, Rheinfelder's focus lies on lexicalized locutions, not on productivity.

Grammars written in the tradition of historical comparison share the same principles: "Die Form des Adverbiale ist eine dreifache, nämlich entweder ein einfaches Nomen oder ein Adverbium oder ein durch eine Präposition verknüpftes Nomen [...]”2 (Meyer-Lübke 1972 [1899], vol. 2, §418). In principle, Meyer-Lübke's term Nomen includes adjectives, but the discussion of the data concerns nouns in the narrow sense. Beckmann's (1963) study on the prepositional followers of the Latin instrumental ablative in Late Latin and French only deals with the combination of prepositions and nouns. The only PA adverbial mentioned in Brunot's (1905-1979) first volume of the Histoire de la langue française, on Old and Middle French, is de legier. He provides no further analysis, but the example is another case of a PA adverbial used in the old language that has disappeared: de léger is not used in current standard French. The PX-pattern is completely lacking in the five volumes of Nyrop's Grammaire historique de la langue française (1979 [1914-1960], vol. 5, 142-151). Zink’s Morphologie du français médiéval (2000, 240s.) only mentions univerbations such as encore, parmi, etc., and one PAdv adverbial, a certes. This is certainly due to its morphological approach, but it underlines the fact that usual approaches do not focus on PX-patterns because these patterns are "not morphological but syntactic", or, in syntax driven work, "not grammatical/syntactic but lexical", etc. Alessio (1955) briefly mentions the formation of adverbs by "composition", including the PA adverbials à present, en général, d'ordinaire. But none of these authors tries to explain the role of PX-pattern in the history of French, not even as a possible instance of mainstream analyticity in the transition from Latin to Romance. Strangely enough, discussing Fr. de vrai, de bon, de juste and It. di giusto, Plattner (1907, 180) argues that there is no need in language for such combinations and, consequently, no explanation for their existence.

PA-patterns have also been analyzed from the point of view of historical word formation by Darmesteter (1967 [1893], 80-82). This author distinguishes three types: The first type combines a preposition and an adjective: $a$ certes, $a$ longes, de primes, par certes, wrongly confounding the final adverbial $-s$ in certes etc.

2 'The form of the adverbial is threefold, that is, either a simple noun or an adverb or a noun linked by a preposition'. 
with the plural of the adjective. The second type combines a preposition and a "neuter adjective": à present, à droit, à tort, d'ordinaire, pour de bon, pour sûr, etc. The series is rather heterogeneous since he also includes au plus, de même, du moins, du tout, en plus, and even pour rire. The third type combines the preposition with a feminine adjective: à gauche, à droite, à la légère, à la dérobée, à la grecque, etc. The fact that he had problems with classifying the PX-patterns according to the usual criterion "preposition + word class" shows (i) that word class distinction is not easy (is $\grave{a}$ droite related with an adjective or with a noun: $\grave{a} l a$ droite?; see Section 2 on Lat. de sinistra et dextra, already without noun) and, consequently, (ii) that almost all types of linguistic units may be used as the second member of a PX adverbial. This means that focusing on PA-patterns may be justified, but it also includes a relevant bias.

Let us turn now to linguistic studies dealing with PA-patterns. To the best of our knowledge, not a single linguistic monograph or article has been dedicated exclusively to the PA-pattern. Recent studies may tackle individual PA adverbials, e.g., Caddéo (2005) on en particulier or Schnedecker (2008) on en tout and au total (if we analyze tout as an adjective). However, these studies only aim at singling out the semantic and functional properties of lexicalized units. Studies on adverbial adjectives do not pay attention to PA alternatives, e.g., Capin (2007; 2010) on Old French petit and un petit, or Bastian/Hammer (2005) on bref. The only author who clearly analyzes the PA-pattern as an extension of adverbial adjectives is Robert (1886, 109-124). In a short paragraph at the end of his chapter on adverbial adjectives, he argues that PA-patterns are used either because other adverbs are missing or in addition to existing ones. He mentions the examples of à plein, $\grave{a}$ plat, à nu, à neuf, à propre, à present, à sec, de sombre, de léger. By contrast, thorough books written on adverbial adjectives from a diachronic (Heise 1912) or synchronic perspective (Grundt 1972, 20th century) do not include the PA-pattern. To put it in more general terms, modern linguistic studies tend to disregard variation in this field. The only topic systematically discussed in this sense is the relation of adverbial adjectives and adverbs in -ment (e.g., Heise 1912, 1027-1030), but not the obvious proximity between cases such as léger, de léger, à la légère, avec légèreté.

Corpus studies such as those quoted in the previous paragraph do not really help regarding variation analysis since they semasiologically study units that are chosen ex ante, e.g., en particulier, or they follow usual metalinguistic categories such as "adverbs in -ment”, "adverbial adjectives”, etc.

Methodologically, the study of variation should include reading since one cannot previously know all possible variants. In her onomasiological corpus study on adverbials in 20th century French novels explored by reading, Kofler (2007, 21) observes that PX-patterns have to be ranked second in terms of fre- 
quency, adverbs in -ment being placed first. Hence, PX-patterns are very relevant in literary style. The main reasons for using PX-patterns are (i) the unavailability of equivalent adverbs in -ment (67 percent) and (ii) the choice of an equivalent adverbial for stylistic reasons (33 percent). Only 10 occurrences out of 134 PX adverbials are PA adverbials, with one productive formation in slang literature: $\grave{a}$ la surprenante. Consequently, PX adverbials are not marginal in contemporary literature, but the PA-pattern indeed turns out to be marginal. Nevertheless, Nøjgaard's (1992/1995) exhaustive onomasiological corpus study on French adverbials in a literary corpus of the 1980s (some 100 books) provides instances of numerous PA-patterns, albeit without further analysis (see his functional classification [vol. 3, 405-424] and the alphabetical list [ib., 462-476]). A similar attempt to exhaustively document all syntactic and morphological features of French adverbials is Gross (1986). Even if corpus and method are not clearly explicated, the lists provided at the end of the volume contain many PA adverbials.

In a recent corpus study on "prepositional locutions", Blumenthal $(2017,123)$ examines "un phénomène nouveau de grande envergure, lié à l'émergence de certaines locutions prépositionnelles" used for structuring discourse in modern texts, but the units observed all belong to the PN-pattern, e.g., en fait, dans la perspective, dans l'optique, au regard de, dans le cadre de, etc. This shows at least that PX is a highly flexible, permanently available means of constructing phrases that may satisfy new needs by integrating units as a second member of a prepositional phrase without relevant restriction due to word class. Over time, productivity, lexicalization, as well as outdating and loss, are permanently at work. This may be held as a "universal" of Romance languages since their beginnings. PA adverbials seem to belong to the almost outdated units.

While most recent studies insist on subtle semantic, functional, and pragmatic differences between closely related units (on en particulier and particulièrement, cf. Caddéo 2005, 189), refusing the idea of synonymy, some authors who put diachrony under scrutiny feel that these differences are subsequent linguistic developments or even modern ideas projected onto the past, e.g., Plattner (1905, 228) on à/pour témoin:

"Es ist vielmehr eine der zahlreichen nachträglich gemachten Distinktionen, die den Zweck haben, in den Fällen, wo eine ältere Ausdrucksweise sich neben der neueren erhalten hat, jeder von beiden ein eigenes Gebiet zuzuweisen". ${ }^{3}$

3 'We deal rather with one of the numerous distinctions made ex post that aim to single out a specific domain of usage for every unit, each time diachrony produces alternative expressions' (our translation). 
In the same vein, Nilsson-Ehle $(1941,11)$ criticizes the obstinacy of looking for semantic differences between sagement/avec sagesse, ardemment/avec ardeur, attentivement/avec attention, etc. (cf. Klein 1973). The first systematic discussion of the apparent synonymy of pairs such as aveuglément/à l'aveugle, étroitement/à l'étroit, grandement/en grand, etc., can be found in Lafaye (1861, 93-99). For this author, adjectives are systematically nominalized when entering a PA adverbial. It is noteworthy that Hummel (2014b; 2019a) observes a similar situation of initial synonymy in Spanish. Âlvarez-Prendes (2018) notes that the sentential functions of both Fr. sérieusement and Sp. en serio, which convey the speaker's attitude 'Let's talk serious', diachronically start from equivalent manner modification of the verb. It is interesting to note that Fr. sérieusement developed this function while Sp. seriamente left it to en serio. It seems that the old language is characterized by the coexistence of potentially equivalent alternatives as well as idiosyncratic individual preferences between adverbs in -ment(e), adverbial adjectives, and PX-patterns. This does not mean that the use of a preposition, for instance, does not create a basis for functional differentiation. It only means that such processes had, at best, started. No standardization had tried to fix differentiating properties. It will therefore be particularly interesting to study the usage of these patterns in the old language. It is noteworthy that the work on Romanian generally foregrounds the synonymy of adverbial adjectives and PA adverbials, the latter being simple "reinforcements" of the former (see Section 8).

\section{Italian (Stefan Koch)}

As for Italian, according to the basic literature (e.g., Serianni 1988, 412, 414s.; Dardano/Trifone 1997, 338-345; Ceppellini 1999, 67-69, 306; Renzi/Salvi/Cardinaletti 2001; Maiden/Robustelli 2000, 203-205; Prandi 2006, 324; Berruto/Cerruti 2011, 148-152) the PX/PA-pattern is still in frequent use, if not productive. According to Serianni $(1988,415)$, "si tratta di una categoria dilatabile quasi all'infinito e dei confini non sempre netti". For PA, just think of combinations such as da solo, d'improvviso, di solito, di continuo, a lungo, in secco, alla larga, al più presto, sul serio, di nuovo, di rado, di recente, di sicuro, di molto, di nascosto, per prima, in grande, di certo, etc., all attested in the standard variety of Italian. Rohlfs (1969, 246), the classic reference on historical grammar of Florentine/Italian as well as Italoromance varieties and dialects, mentions "moltissimi casi" in some Italo-Romance idioms, without going into detail. Apart from this, hints of the PA-pattern and detailed analyses of it are very scarce, especially in modern linguistic manuals and grammars. The classics on Romance languages (Elcock 1960; Tagliavini 1959) as well as current manuals, specifically the chapters 
on Italian in the three volume Romanische Sprachgeschichte (Ernst/Gleßgen/ Schmitt/Schweickard 2003-2008), the Italian chapters in The Oxford Guide to the Romance Languages (Ledgeway/Maiden 2016), and the standard linguistic manuals on Italian (LRL = Lexikon der Romanistischen Linguistik, vol. 4 [1988]; Manuale di linguisitica italiana [Lubello 2016]; Grossmann/Rainer 2004), treat the PA-pattern only superficially, if at all (e.g., Skytte 1988).

Elcock (1960) and Tagliavini (1959) simply do not mention Italian adverb formation. In the Romanische Sprachgeschichte (2003-2008), no comments on PA adverbials can be found in the relevant chapters. The formation of adverbs or adverbials does not seem to matter to Ledgeway (2016a; 2016b) and Loporcaro/ Paciaroni (2016) in the exhaustive new Oxford Guide to the Romance Languages either. Cruschina/Ledgeway (2016) and Salvi $(2016,999)$ focus on the syntactic behavior of adverbs in Romance but skip morphology and word formation. Rainer $(2016,513 s$.) only studies -mente formations in earlier stages of written Southern Italian. Similarly, Grossmann/Rainer (2004, 472-491) strictly focus on morphological means to form adverbs. In the above mentioned LRL 4, only Skytte $(1988,50)$ briefly mentions other adverb formations, such as the already univerbalized PX adverbials infatti, almeno, adagio, or "locuzioni fisse" such as all'improvviso. Vanelli (1988) completely neglects adverbs, as does Renzi (2009). The same goes for all the contributions in Lubello (2016), which do not seem to deem adverb formation, in particular analytical patterns of the PX type, of any major interest. D'Achille $(2016,181 \mathrm{~s}$.) only notes an extension of the use of -mente adverbs in recent Italian due to tendencies of using them as phrasal modifiers and instead of simple adjectives in answers (like perfettamente instead of perfetto). Even in Pecoraro/Pisacane (1984), a work exclusively dedicated to adverbs, PA adverbials are not mentioned.

Similarly, we do not find extensive documentation of the PA-pattern in works on Old Italian. The chapter on adverbs in the two volume Grammatica dell'italiano antico (Salvi/Renzi 2010) does not include the PA-pattern, and the chapter on prepositions again deals almost exclusively with PN-patterns (cf. Piunno 2018, 165-179 for present day Italian). One single case may be mentioned, and only if we accept the adverb lunge as an assimilated member of the PA-pattern: an explanatory remark in brackets equates di lunge da with lunge da (Salvi/Renzi 2010, 623). On the other hand, lunge probably directly stems from the Latin adverb longe and was transmitted into modern Italian as an adverb, so di lunge $d a$ is more a PAdvP-pattern. In an unpublished paper presented at the International Congress on Romance Linguistics and Philology (Rome, 2016), Dardano/Frenguelli/Colella quoted the example per lo fermo, but their further analysis only dealt with -mente adverbs such as fermamente, sicuramente, certamente, veracemente. 
Even in the contemporary grammars of impact, we only find the same examples cited over and over again, in newer grammars almost exclusively under the label locuzioni avverbiali. The term gained supremacy over other terms in the 19th century (cf. Consales 2018, 332) but implies once again an interpretation of PX adverbials as pertaining to the lexicon and not to analytic word formation/creation (i.e., a regular, productive pattern of forming adverbs/adverbials). Lonzi (2001, 375-377), in the second volume of the Grande grammatica italiana di consultazione on contemporary Italian (Renzi/Salvi/Cardinaletti 2001), mentions only two PA adverbials as "adverbial locutions", without further analysis (alla larga, a male). In eterno is analysed as an equivalent to the sentence adverb eternamente (cf. Lonzi 2001, 386), together with d'ordinario, di converso as other examples for PA on the same page.

In older grammars, grammatical treatises, studies, or linguistic works of another kind (see also the reference to Diez in Section 3), the PX-pattern (and the PA-pattern) seems to be included in a much more natural way, but still, this mostly concerns single cases and not the pattern as a whole. This may have various reasons, but mainly, examples are only given if the PX/PA-pattern is already lexicalized and is the most common adverbial with that specific semantics (compared to the -mente and bare adjective alternatives). In descriptive linguistic works from the 19th century, we often find the PX-pattern as a regular way of forming adverbs, completely equal to -mente, converted adjectives, and the -one/-oni type. But it is implicitly clear, though, that the authors simply list all possible ways of formation of adverbs or all possible forms of appearance of adverbs/adverbials, without claiming that the different patterns are also equally frequent in the respective language system of the time (see below for some eclectic examples). The following paragraph will tend to investigate this in more detail. For an overview on adverbs in Italian grammars since $1516 \mathrm{cf}$. Consales (2018).

The first ever grammar of Italian (Florentine) in Italo-Romance (unpublished until modern times) comes to us in a handwritten copy from 1508. It is the socalled Grammatichetta Vaticana, mostly attributed to Leon Battista Alberti (cf. Grayson 1964, XVII-XLIII). It dates back to somewhere between 1434 and 1443. While later grammars are clearly of the normative kind, Alberti still seems to try to observe and describe Florentine speech as it is, applying for the first time Latin grammatical terms on the volgare (cf. Grayson 1964, XLIII-XLIV). The grammars of the cinquecento and seicento mostly sustain a normative approach, the motto(s) of which might be if the "tre corone" said it, it's good.

In Alberti's chapter on adverbs (ed. Grayson 1964, 57s.), we only find monoverbal adverbs destinated for different pragmatic uses. No single PX adverbial is mentioned. We come across just the interesting remark that adverbs can be nominalized by adding the article. The only comment on regular adverb formation, at the end of the chapter after listing uninflected adverbs, is the following: 
"Item, a similitudine della lingua gallica, piglia el Toscano e nomi singulari femminini adiettivi e aggiungevi -mente, e usagli per avverbi, come saviamente, bellamente, magramente" (Alberti, ed. Grayson 1964, 58).

The first printed Italian grammar, by Gian Francesco Fortunio, appeared in Ancona anno 1516, printed by Bernardino Guerralda. We cite the edition from 1539 (Venice: printed by Bindoni/Pasini). Though Fortunio mostly treats uninflected, fixed, and lexicalised adverbs like assai, altrove, ovunque (Fortunio 1539, 33s.) and adverbial adjectives (31), he at least mentions en passant some PX adverbials. By doing so, he obviously considers them no more special than any other adverb or adverb formation; e.g., he states, "Rado, \& di rado dicesi per raro aduerbio" (Fortunio 1539, 33), or mentions a passo a passo as synonym for a poco a poco (cf. Fortunio 1539, 33).

In Bembo's classic Prose della volgar lingua (1525), there is scarce proof of PXpatterns. Only in some chapters do we find them, very randomly, as alternatives for -mente, such as in book 3 (ed. Dionisotti 1966, LX, 278) rattamente, spacciamente, and in fretta for prestamente. But sometimes the reader comes across interesting comments on adverbials, such as "Ė Per poco, che s'è posta alcuna volta, in vece di Quasi, dal medesimo Boccaccio" (ib., 284), where we have one of the few instances of the PA-pattern. There is also "E Tale, in vece di Talmente detta alle volte da' poeti; e Quale, in vece di Qualmente, ma detta tuttavia piú di rado" (ib., 283), where Bembo comments on the use of adverbial adjectives (here very particular ones) instead of -mente adverbs and uses a PA-pattern adverbial himself ( $d i$ rado).

Franciosini (1638 [1624], 123-134), in his Spanish-Italian grammar, cites various PA adverbials which could be influenced (especially when cited as primary option) by their Spanish counterparts; e.g., Franciosini (ib., 134) mentions, as possible Italian equivalents for Spanish $a$ escondidas, PA adverbials as well as -mente adverbs: di nascosto, segretamente, di soppiatto, furtivamente.

Veneroni (1713, 180-184), a bilingual learners' grammar (Italian and French), only lists "classic" examples with -mente, with the following exceptions (PA or PAdv.): da dovero (ib., 182), di gran longa (ib., 183), as well as the always cited (a) poco a poco (ib., 182).

Di Castelli (1748, 122-134, 360-378), in a list of Italian adverbs and their syntactic description, gives in an estimated $35-50 \%$ of his examples adverbs of the PX-pattern (among them many PA adverbials). In his subchapter on adverb formation (ib., 122s.) he completely naturally mentions PX-patterns as one method of forming adverbs, though concentrating exclusively on PN-patterns. This might be explained by the fact that the author seemingly classifies everything that follows a preposition as a noun. Another interesting point in Di Castelli $(1748,133 \mathrm{~s}$.) is the 
fact that the author acknowledges the principal and general possibility of substantivizing adverbs, even those that consist of a PP, by preposing the article (il di sopra; ib., 133). This could be a possible proof that adverbial PPs are simply considered as one complex adverb. This remains to be further investigated; however, since Di Castelli's examples only refer to the pattern DetPP, it could at least be an argument for PX as a third alternative for adverb formation with nearly no restrictions.

Finally, in a more specific work that exclusively deals with adverbs, the $D^{\prime} A v$ verbj, Particelle, Preposizioni e Di Frasi Avverbiali Libretto by Paolo Rolli (London 1741), we come across numerous mentions of PX adverbials all over the whole libretto. Rolli (1741), in the prefazione, explicitly sustains that adverbs of "regular" formation, i.e., of the -mente type, are not included in his work for being regular. Interestingly, the -mente type is, for Rolli, the only regular formation of adverbs. Throughout the text, we find numerous PX-pattern adverbials. Most of the time those PP are either part of longer adverbials, such as (ib., 1) ivi a tre miglia, a capo in giù, a lungo andare, or are part of a verbal phrase (participle) like fatto a mano, which Rolli seemingly considers some kind of adverbial as a whole. Rolli's work is divided into three columns on every page, where he gives the adverbial or prepositional equivalents in the left-hand column, an English translation in the righthand column and the proper adverbial or frase avverbiale (in his terms) of interest in the column in the middle. There we find PX adverbials in abundance and even many cases of PA, such as in breve (ib., 10), di leggieri (ib., 18), a lungo (ib., 19), in palese (ib., 23), per altro (ib., 24), da poco (ib., 25), di rado, di raro (ib., 28, once again a particular case of interest), a sghembo (ib., 30), a tanto (ib., 31), a/da/per traverso (ib., 32) and again the always cited a poco a poco (ib., 1). Once again, all examples are included completely naturally but, within the logic of Rolli, as fixed elements and not as results of active and still productive word (i.e., adverb) formation.

Finally, we treat two early works on Italian grammar from the 1870 s, Sauer (1874) and Demattio (1876). These are not yet influenced by modern grammaticography the likes of Salvi/Renzi/Cardinaletti (2001) where PX is merely mentioned as a lexicalized sideway of adverbials.

Sauer $(1874,134-144)$ mentions a few PX adverbials, such as per tempo and $a$ poco a poco. He lists them among adverbiale Ausdrücke 'adverbial expressions' and locuzioni avverbiali (which by that time seems already to be the standard term). This goes along with his general remarks on adverb formation, where he primarily accepts -mente as a productive pattern (ib., 134s.). He concedes, though, some cases of the -one and of the pure adjective type (Type A, see (1)) but signalizes their particularity (i.e., most probably not considering them as productive patterns; cf. ib., 135s.). The most interesting remark from a typological and mor- 
phological standpoint is the fact that he underlines the possibility of forming adverb superlatives even from non-inflected adverbs like assai and PN-patterns like per tempo: assaissimo 'very, very much in abundance' and per tempissimo 'very early' (ib., 135). The second example shows, once again, that some PX-pattern adverbs might already be considered, as a whole, as an adverbial complex (see above). All in all, Sauer (ib., 141) considers the PX-pattern very frequent, though not giving a corresponding number of examples, which also might imply that, for the author, they are completely natural and logical in their formation, so there is no further need to mention them in detail. However, he also states that adverbiale Zusammensetzungen 'adverbial compositions (synthetic and analytic)', among them PX-patterns, can be found in any dictionary, which points to lexicaliziation. At any rate, lexicalization processes may go hand in hand with the productive creation of new units. This seems to be the case.

Demattio (1876, 99-102) names two types of adverb formation via suffixation, interestingly the -one type in first place and the -mente type in second (though probably very well aware of the true frequencies). He then goes on to describe other adverb formations, among them, presented completely naturally, the PXpattern. He first generally remarks (ib., 100; our italics) that

"Del resto in maggior numero i concetti avverbiali si esprimono mediante aggettivi e sostantivi, in relazione con un caso obliquo, scompagnati da preposizioni o coll'accompagnamento di esse".

Later on, he gives explicit examples of locuzioni avverbiali with $d i, a$, and in, emphasizing their high frequency (ib., 101). And, as first option, he provides many examples of the PA-pattern. This might be simply based on reasons of systemization, but is still a fact not to be neglected.

Concluding, Sauer and Demattio, as well as some other older grammars, share certain characteristics in the observation of the PX-pattern. In the first place, they imply the complete commonness of such forms, not even mentioning that they might possibly be fossilized. PX is always treated as something that is also possible or can be found, and that those formations (whether productive or not) obey the logical linguistic rules of using prepositions. Where it makes sense, those PP can form adverbs/adverbials. Mostly, these works cite lexicalized combinations in lists. Within the PA-pattern, di rado seems the most commonly cited (because most lexicalized?) form. Sometimes PX adverbials are implicitly tackled when treating comparatives and superlatives.

Concluding, we may sustain that, in terms of the PX- and, specifically, the PApattern, older works and grammars are often of more interest to the researcher. They are not as normatively influenced by modern standard usage as newer approaches and so show a very natural existence of PX, and the PA-pattern in parti- 
cular, at the respective point in time (i.e., the publication date of the works). This also leads to the conclusion, though in contemporary treatises over the last fifty years the locuzioni avverbiali formed by PPs have been given little attention, that the PA-pattern is not only still present in today's (standard) Italian, but probably can be found in even greater number in spoken language. It is at least tempting to assume that PA might still work as a regular way of ad hoc formation of adverbs, especially in the South, where -mente (cf. Silvestri 2017, 174-175) is not very present in nonstandard and especially not in dialect varieties. Looking at Rohlfs (1969) and the cited grammars between the 15th and 19th centuries, the PA-pattern does indeed suggest to be a promising research field, where by far not everything has yet been systematically observed, described, and linguistically analyzed. For Italo-Romance, there might still be a great upside concerning the investigation of this particular subject within the vast field of adverbials.

\section{Portuguese (David Porcel Bueno)}

Adverbs and adverbial locutions have been an important part of the linguistic historiography of Portuguese, and studies related to it have been constant since the first Portuguese grammars of the 16th, 17th, and 18th centuries (Ricós 2008b, 2011; Palma 2009, 9-13). If we take a closer look at the contemporary grammars, we observe that their study varies depending on the adopted perspective (morphosyntactic, semantic, phraseological, or discursive). Regarding so-called adverbial locutions, Vázquez Cuesta/Mendes da Luz (1971, 112-117) mention some of the most frequent PX-patterns in European Portuguese (por pouco, em vão, de repente, de súbito, a súbitas, de bom grado, de boa mente, de afogadilho, às avessas, às escondidas, às cegas, às escuras, à antiga, a torto e a direito, etc.), whereas Cunha/Cintra (1984, 540-542) refer to these PX-patterns in a wider and more extensive way and also provide a classification in accordance with their semantic value (cf. Móia/Alves 2004, for the study of differences between European and Brazilian Portuguese in the use of temporal adverbials). According to the latter authors, adverbial locutions can express affirmation or doubt (por certo, com certeza), intensity (de muito, de pouco, de todo), place (à direita, de dentro, de cima, de longe, de perto), manner (ao contrario, às avessas, às claras, em vão), negation (de forma alguma, de modo nenhum), or time (à tardinha, em breve, de vez em quando). Moreover, they make an interesting observation that has to do with the position of the preposition (Cunha/Cintra 1984, 541):

"Quando uma preposição vem antes do advérbio, não muda a natureza deste; forma com ele uma locução adverbial: de dentro, por detrás, etc. Se, ao contrário, a preposição vem depois 
de un advérbio ou de uma locução adverbial, o grupo inteiro transforma-se numa locução prepositiva: dentro de, por detrás de, etc.”.

Additionally, in the chapter dedicated to adverbs, Bechara $(2001,288)$ mentions "combinações com advérbios". These combinations can express time or place and they indicate their syntactic function by using a preposition (de longe, por agora, de sempre, etc.). In this regard, Bechara distinguishes two combinations with adverbs: On the one hand, there are those adverbs that are linked to a preposition (em frente, em cima, depressa, apenas, em baixo) and serve ("por hipotaxe") as simple prepositions "a introducir um adjunto adverbial" (ib., 289); on the other hand, there are adverbial locutions in the strict sense, which are made up of one preposition and one noun and have an adverbial function (com efeito, de graça, às vezes, sem dúvida). In the second case, "a preposição, funcionando como transpositor, prepara o substantivo para exercer uma função que primariamente não lhe é própria" (ib.). According to the author, this noun can be masculine or feminine, singular or plural, even though Bechara omits that these PX-patterns are also built on an adjective, as can be observed in the examples that he himself mentions (ib., 290). In the vein of Cunha/Cintra, Bechara also analyzes prepositional locutions (ib., 301), which are made of one adverb (or adverbial locution) followed by a preposition de, $a$, or com: por causa de, em frente a, de acordo com, etc. At the end of the chapter, the author provides a list of the most common PXpatterns and PXP-patterns (ib., 305).

The monumental Gramática do Português (Raposo et al. 2013, 1581) offers an approach which is closer to phraseology. Adverbial locutions are defined as a combination of two or more words with a high degree of fixedness (syntactic and semantic) and idiomaticity. Therefore, there are very few possibilities of modifying internal elements, as opposed to regular prepositional syntagmas (ib., 1583). The grammar also points out that the PA-pattern is the one that integrates the highest number of locutions and is the most productive one (à alentejana, ao redor, de novo, às cegas, em comum, em particular, em vão, etc.). Similarly, it is interesting to see the difference established between adverbial and prepositional locutions. According to this grammar, adverbial locutions are characterized "por terem um sentido completo, não podendo combinar-se com um complemento ou sequer recuperá-lo contextualmente" (ib.), unlike prepositional locutions, which accept and even require a complement. The presence or absence of such a complement can help us distinguish adverbial locutions from prepositional locutions.

Descriptive grammars of Portuguese follow a similar current. Neves (2000, 231-234) mentions the PN-pattern as "advérbios perifrásticos ou locuções adverbiais" and shows that the latter also include the PA-pattern. From a syntactic point of view, she points out that the PX-patterns can act in different parts of a 
statement (de repente, de supetão, às escondidas, por milagre, etc.). For his part, Azevedo $(2018,210)$ believes that the syntactic position of adverbs can be occupied by so-called adverbial locutions, since they

"se prestam à expressão de variações aspectuais do verbo (de vez en quando, às vezes, de hora em hora, por pouco, de repente, de supetão), intensificações do processo verbal, muito comuns na língua falada informal (à beça, pra burro, pra cachorro), e aos modos do processo verbal (de bruços, de lado, de mão e mão, em pé, com pressa, aos trancos, por milagre)”.

Moreover, he claims that diminutive forms such as à tardinha or de manhãzinha are typical of the informal register, written or spoken (ib., 211).

Castilho (2010, 541-582) works fundamentally with the syntactic functioning of adverbs and their position in a clause. At the same time, he divides them into three semantic classes: "predication" (modalization, qualification, quantification), "verification" (focus, inclusion, affirmation/negation), and "deixis" (time, place). He does not draw any distinction between adverbs and adverbial locutions.

Apart from grammar books, the study of the PX-pattern has been linked to the general description of so-called "expressões cristalizadas", "frases fixas", or "expressões idiomáticas”, in Brazil (Araújo-Vale 1999; 2001) and in European Portuguese (Vilela 2002; Baptista/Fernandes Graça/Correia 2005). These expressions, as we know, are influenced (or even determined) by the cultural identity of a linguistic community (Jorge 2001).

Regarding adverbial locutions in the strict sense (including some PA-patterns), there have been studies of their use in very specific discursive genres (Andrade 2005; Soares 2012; Oliveira/Cezario 2012). Other papers focus on the presence of somatisms in this type of pattern (Bojilova 2009).

From a synchronic perspective, one of the papers that best defines the uses and features of adverbial locutions is Costa (2008). According to the author, adverbial locutions are made of different schemes, notably the scheme made of one preposition and one "expressão nominal", modified or not by one adjective (de repente, em vão, em rigor, em comum, em boa hora, à esquerda, à direita, etc.), and the scheme made of one preposition and one adverb preceded or not by a determiner (de longe, de perto, a bem, a mal, por alto, desde logo, por perto, etc.) (ib., 22). Regarding their semantic value, the PX-patterns with adverbial function can be grouped as follows: "locuções adverbiais modificadoras de predicado de localização temporal” (em breve), "locuções adverbiais modificadoras de predicado de localização espacial” (à esquerda, de fora), "locuções adverbiais modificadoras de predicado de modo" (em vão, de ponta a ponta), "locuções adverbiais modificadoras de predicado de quantificação ou de intensidade” (um bocado, um bocadinho), "locuções modificadoras de frase com valor avaliativo" (sem dúvida, 
em boa hora, à primeira vista), and "locuções modificadoras de fase com função focalizadora” (em particular, em especial) (ib., 24s.).

Another important paper for the study of the PA-patterns in Portuguese is written by Palma (2009), who investigates lexical and syntactic implications of these types of fixed expressions in Portuguese. The theoretical and methodological framework is based on Gross (1986), which concerns the compound adverbs in French. Before linguistic analysis, Palma offers some identification criteria for commonly named "advérbios compostos" based on an ideal structure "Preposição + Determinante + Elemento lexical de natureza nominal + Modificador, geralmente um elemento lexical de natureza adjetival" (Palma 2009, 35-43). All these elements can be simultaneously present or not. The presence or absence of these members is used as a classifying criterion. Therefore, the adverbial PC scheme would be made of a preposition (P) and a constant lexical element (C): a pulso, ad eternum, de boca, sem rodeios. The scheme PDETC, as opposed to the previous one, allows for the introduction of a determiner (à bruta, de uma tirada, na diagonal). The adverbial schemes PCA and PAC present a lexical element, generally a type of adjective, in the position of a modifier (à viva-forza, de comum acordo, de mão beijada, à vista desarmada) (ib., 44s.). With regard to PCDC, PCPC, PCDN, PCPN groups (ib., 45-48), we should mention that their criteria coincide in many cases with the features of socalled complex prepositional locutions (à luz de, a peso de, em abono de, à margen de, ao som de, por falta de, por amor a, de acordo com, à excepção de, etc.). Palma (ib., 104-115) describes, from a contrastive perspective, the adverbial locutions that are the same in Spanish and in Portuguese, and she does it by comparing two unpublished lexical repertoires elaborated by herself: the "Diccionario electrónico de los adverbios compuestos del español" and "Dicionário electrónico dos adverbios compostos do Português”.

It is precisely this contrastive approach that has guided some diachronic research on adverbial locutions. Ricós (2006) studied certain PX-patterns common in the Spanish and the Portuguese of the 16th century and she did the same with Galician and Portuguese, although focusing more on PXP-patterns in this case (Ricós 2016). She also examined adverbial locutions with the preposition $a$ and an adjective in Spanish and Portuguese. She came to the conclusion that it is one of the most productive patterns for the creation of Ibero-Romance adverbial locutions (Ricós 2008b, 1036), especially in the case of Portuguese: à antiga, às cegas, às escuras, à brava, à bruta, às caladas, às escondidas, às ocultas, às claras, às boas, às sabidas, etc. As she points out, the key to their success is possibly the fact that they can be connected with other complex units through a copulative conjunction, such as Sp. a tontas y a locas, a las duras y a las maduras, etc.

From a lexicographical point of view, Costa (2009; 2012) studies spatial and temporal locutions from a historical perspective. Despite the fact that the scholar 
does not carry out exhaustive research, she mentions the Latin background of these PX-patterns: às costas (costA, -AE), em cima, per cima, de cima (CIMA, -AE), no fundo, ao fundo (FUNDUS, -I), no princípio, por princípio (PRINCIPIUM, -II), às vezes (vix, -CIS), em breve (BREVI, -E), de novo (NovUs, -A, -UM).

For her part, Cezario (2016) tackles the adverbial locutions used most frequently in the letters written by Jesuits in the 16th and 17th centuries and also the adverbial locutions documented in official Brazilian letters from the 19th century (Cezario 2014). The latter study is similar to that published by Paulino Machado in 2013. Cezario (2005) reveals that some PX-patterns documented in religious texts always appear in a preverbal position, and she analyzes the specific case of às veces and the prepositional locution à luz de.

Nevertheless, in none of these papers do we see a clear distinction between free syntactic groups and phraseological units characterized by their fixedness. Unlike in these papers, Ricós (2008a; 2011) investigates, respectively, the adverbial locutions in Portuguese linguistic treatises before the 19th century and those in Portuguese trilingual dictionaries of the 17th century, following the model for a study of phraseological units proposed by Echenique (2003).

One characteristic that we can consider common to all Ibero-Romance languages is the abundance of PA-patterns with a clitic in feminine and in plural. As García Benito argues $(2009,11 s$.$) , this frequency is increased in Portuguese, espe-$ cially when we refer to adverbial locutions: às escuras, às escondidas, às cegas, com a sua fisgada, às furtadelas, às direitas, às claras, às carreiras, às mil maravilhas, às quinhentas, etc. Regarding the origin of these schemes and their productivity, Garcia-Page $(2008,242)$ considers that it may be due to the transformation into feminine plural of some Latin neuters, whereas Delbecque $(1997,220)$ attributes it to the grammatical value "del término marcado frente al no marcado", that is, as opposed to the masculine, the feminine is presented as "marked", formally and semantically, and that is why it is suitable for locutional uses.

The so-called process of grammaticalization of adverbs has been a muchstudied subject, although the PX-pattern as a third way has not always drawn attention (Almeida 1984; Costa 2003; Castilho 2004; Barbosa 2006). In the case of Brazilian Portuguese, Martelotta (2012, 23) only mentions univerbations stemming from PN- or PAdv-patterns (acima, apenas, amanhã) and PP-patterns (depois). In the domain of manner adverbs, the only relevant type mentioned is com segurança (ib., 54).

Ilari et al. $(1990,88)$ use the notion of scope (a combination of contents affected by the adverb itself) to talk about the semantic function of adverbs and provide as an example the influence that the adverb "não" (scope) can have on locutions such as con certeza or en el fondo. Similarly, Neves (2002) discusses the semantic functions of adverbs of place such as em baixo de (which points to a 
relative position) or em frente de (anteposition), although, for us, these PXP-patterns are not adverbial locutions but prepositional locutions.

Once again, in their paper about "advérbios aspectuais", Ilari et al. (2002, 141) show that some adverbial locutions are synonyms for simple adverbs which are less frequent in spoken language (às vezes = ocasionalmente; sem parar = ininterrumpidamente) and argue that adverbial locutions are more frequent than simple adverbs in spoken Brazilian Portuguese. As we previously indicated, the concept of a locution is slightly ambiguous in these papers since they adopt a functional perspective and do not attach importance to the fixedness nor to the idiomaticity of the PX-pattern (Oliveira/Cezario/Martelotta/Furtado da Cunha 2013).

Regarding the catalogue of Portuguese PA-patterns, it should be recalled that, just as happens in other languages, there are lexical repertoires that contain a great number of PA-patterns. If we state that for European Portuguese the papers written by Santos (1990), Neves (1992), Simões (1993), and García Benito (2006) are fundamental, then for Brazilian Portuguese those would be Macedo Rocha (2011) and Carneiro da Silva (1975). Even though the latter has been ignored by scholars and critics, her research collects a vast number of PX-patterns, especially in Brazilian Portuguese.

\section{Romanian (Adrian Chircu)}

Romanian PA adverbials have not yet been systematically studied, although there is significant evidence of their use in Old Romanian. A first inventory of PA adverbials can be found in Histoire de la langue roumaine by Ovid Densusianu (1997, 586-609), which was published in the first half of the 20th century (vol. 11901 , vol. 2, fasc. 1-3, 1914, 1932, 1938). Part of his data was later taken up by Frâncu (2009, 133-135). Densusianu $(1997,586)$ states that the Romanian language is particularly rich in adverbial morphology. Although he does not suggest a systematic morphosyntactic or etymological analysis, he provides the first large account of adverbials in Old Romanian that contains PA adverbials. In fact, he lists them as "phraseological units", e.g., amăruntul 'in detail, on a small scale', cu amar 'bitterly', cu derept 'fairly and equitably', cu destul or cu de destul 'enough, amply', cu dulce 'affably, kindly', cu lin 'affably', cu nederept 'unfairly, wrongly', de biu 'sufficiently', de destul 'sufficiently', de nou 'again, newly', îndelung 'for a long time', inderept 'upright, standing' (ib., 586-609).

It was not until the 1960s that another author, Ciobanu (1961), tackled Modern Romanian adverbials in a way that included prepositional adverbials. According to this author, prepositions are used to determine "movements" of the event 
denoted by the verb (ib., 46), as is also the case with the French preposition en in en haut / en bas, but she provides no further analysis. Her examples only contain adverbs of place with adjective-adverbs being notably absent (încolo in that direction', in sus 'top'). However, discussing the function of the preposition de, she states that it may join adjectives, expressing the same concept as the corresponding adverbial adjective (Type A). Thus, de sigur conveys the same affirmative function as the simple adverbial sigur 'that's true, surely', with the former being simply reinforced by the preposition (ib., 51). By contrast, in the case of inconti$n u u$, the prefix $\hat{\imath}$ adds the concept of duration to the adjective-adverb continuu (e.g., plouă încontinuu 'it rains all the time') (ib., 56). The fact that continuu is a neological adjective shows that the formation of PA adverbials corresponding to adverbial adverbs is still productive in modern Romanian. According to Ciobanu, the use of the preposition in inside adverbials is due to the fact that this preposition frequently appears in adverbial locutions with nuclear nouns: în silă 'without wanting, desiring', în grabă 'in a hurry', etc. Interestingly, in the case of sigur, the same unchanged concept 'surely' can be expressed by the simple adverbial sigur as well as the "prepositioned adverbial" $l a^{4}$ sigur, e.g., a lua la sigur 'to surely get/ take', a merge la sigur 'to go straight'. It is noteworthy that this meaning differs from de sigur, which means that la sigur and de sigur match different parts of the polysemic and polyfunctional adverbial sigur. The preposition pe 'on' is again analyzed as a means to reinforce the adverb, e.g., pe deplin 'fully', pe scurt 'in short', being preferentially used in spoken language (ib., 59). In line with this, the combination of different prepositions (see examples in the following paragraphs) is considered to be typically oral (ib., 62). In sum, according to this author, prepositions combining with (adverbial) adjectives may either change the verbal concept (location, direction), eventually selecting a fitting concept in the polysemy of the adverbial adjective, or simply reinforce it, if meaning and pragmatic function remain unchanged.

In the same year, Dragomirescu (1961) proposes a typology of adverbial locutions where PA adverbials sporadically and sometimes confusedly appear. According to this author, the word class of adjective is less open to form adverbial locutions in comparison to nouns (ib., 63). He mentions common language instances such as din greu 'hardly, arduously', din nou 'again, newly', de-a dreptul 'directly, exactly', cu încetul 'slowly, softly', cu de-amănuntul 'in detail’ (ib., 65).

Ciompec $(1985,87)$ considers the PA-pattern in diachrony, specifying that there is no justification for using prepositions with manner adverbs because they

4 Rom. la is roughly equivalent to prepositions such as Fr. à, Sp. $a$, etc. Ciobanu wrongly considers sigur a noun. 
are synonymous with the underlying adverbial adjective. She observes a tendency to cumulate prepositions inside adverbials, a fact that converts them into constituents of the adverb producing "supercomposed/overcomposed" adverbial locutions. Her list of PA adverbials counts about 15 instances (including prepositional variation), which is smaller than that already suggested by Densusianu: e.g., cu destul, den destul 'sufficiently', cu greu 'with difficulty', cu iuşor 'easily', pre iuşor 'easily', pre încet 'slowly, softly', pre larg 'largely, in detail', cu lesne 'easily', pre lesne 'easily', pre nederept 'unjustly', cu nederept 'unjustly', de nou 'again, newly', in (ntru) scurt 'in short', pre scurt 'shortly'. For Ciompec, adverbial adjectives and PA adverbials freely and synonymously vary in use, albeit the latter may produce effects of reinforcement (ib., 89). She also draws attention to the fact that adverbials generally select several prepositions forming different phraseological units expressing the same meaning (ib., 90).

Nica $(1988,94)$ mentions that in Romanian every qualifying adjective can be used as an adverb, adding that PA adverbials tend to have a modal function at the discourse level, as is the case with desigur or Sp. por cierto (ib., 159s.).

Similar to other Romance languages, in the case of Romanian, studies on adverbs are mostly dedicated to adverbial adjectives only, without checking their possible combination with prepositions (cf., e.g., Mihai 1963, 217; Chircu 2014, 177-187). This holds also for recent thorough studies on the adverb. (Mîrzea-)Vasile (2012; 2013), who foregrounds the widespread use of adverbial adjectives and adverbial participles $(2012,58)$, does not mention the PA-pattern.

In line with this, the grammars published by the Romanian Academy (GLR; GALR) focus on adverbial adjectives. The Gramatica limbii române (GLR) only briefly mentions that Romanian adverbial locutions may include adjectives (din nou), without providing further details (GLR, vol. 1, 304). The authors of the Gramatica limbii române (GALR) observe that the conversion from adjective to adverb is generalized, especially with qualifying adjectives used in common language (GALR, vol. 1, 177). They include the PA-pattern in the class of adverbial locutions, arguing that they entail the nominalization of the adjective, as in cu frumosul 'kindly', din plin 'fully', which may be the starting point for the formation of further "lexicalized locutions” (e.g., pe deplin 'fully') (GALR, vol. 1, 590).

The authors of The Grammar of Romanian (GR) also concentrate on adverbial adjectives (ib., 450). In the same vein, PA adverbials are not directly tackled by the Gramatica de bază a limbii române (GBLR), but it is mentioned that modern Romanian uses unanalyzable adverbials which were transparently composed in diachrony (ib., 307), as with, e.g., destul 'enough, sufficiently' (de + sătul 'full, satiate' < lat. SATULLus 'quite satiate').

PA adverbials are completely lacking in The syntax of Old Romanian (SOR). The authors specify that most adverbs are identical to the masculine form of the 
adjective (ib., 414). They allude to adverbial locutions without mentioning the PApattern.

In his monography on the adverb in Romance, Chircu (2008, 109-114) introduces special sections on PA adverbials in his classification of adverbials in Old Romanian, some of them still being used in modern Romanian with possible morphological changes (IB:, 129, cf. also Chircu 2015, 16). He separates (i) composed adverbials such as îndelung 'long', (ii) preposition plus adjective, as in deplin 'fully', and (iii) preposition plus adverb, as in cu destul 'enough', cu greu 'with difficulty' and cu iuşor 'easily', cu lesne 'easily', de nou 'again'. Chircu $(2015,11)$ adds that the provenance of the Old Romanian texts provides evidence for the use of PA adverbials in all regions, a fact that may entail geolinguistic variation. Chir$\mathrm{cu}$ (ib., 12) further points out that most of the adjectives used in PA adverbials stem from Latin. This corroborates the hypothesis that the PA-pattern follows a Latin model. The author lists the following cases: amar 'bitterly', blând 'lightly', cătinel 'slowly', desert 'empty', derept 'rightly', greu 'difficultly', gros 'thickly', încet 'slowly', iuşor 'easily', larg 'largely', lat 'widely', lin 'slowly', lung 'longly', mărunt 'finely', moale 'softly', plin 'fully', scurt 'shortly', strâmb 'crookedly', tare 'strongly', etc. As shown by Hummel (2019a; 2019b), most of these are also used as PA adverbials in other Romance languages or varieties. The prepositions that combine with such adjectives, often with the same adjective, display rich variation: $c u, d e, \hat{\imath}, p(r) e, \hat{i n t r u}$, etc. The most frequently used preposition seems to be $p(r) e$ 'on': $p(r) e$ scurt, $p(r) e$ blând 'softly', $p(r) e$ strâmb 'falsely', $p(r) e$ d(e)rept 'really', $p(r)$ e ned(e)rept 'unjustly', $p(r)$ e lat 'awry', $p(r) e$ lung 'at length, lengthily', $p(r) e$ curat 'properly', $p(r) e$ necurat 'not properly, miserably', $p(r) e$ măruntu 'in detail', $p(r) e$ cătinel 'softly', $p(r) e$ incet 'slowly', $p(r) e$ lesne 'easily', $p(r) e$ amănunt 'in detail', $p(r) e$ deşert 'in vain', $p(r) e$ destul 'enough, sufficiently', $p(r) e$ iuşor 'easily', $p(r) e$ deplin 'fully, completely' (ib., 14).

According to this author, Romanian has a special type of PA adverbial which takes a "false article", that is, the enclitic definitive article (masculine, singular) -ul, as in de-a lungul 'along', de-a latul 'across', de-a largul 'across, traversely', pe de-a-ntregul 'entirely' (Chircu 2007, 67-75; Chircu-Buftea 2011, 110-118; cf. also $\mathrm{GR}, 435)$. However, if we take into account that the enclitic article in Romanian is realized by free morphemes in other Romance languages, the structure clearly recalls constructions such as Fr. à la longue 'in the long run', Sp. a las claras '(bring) to light', etc. (see Section 3).

In sum, Romanian PA adverbials display a clear analogy to Romance in general. Variationist tendencies seem to be particularly developed in Romanian over time and space. In this sense, the frequent combination of several prepositions with the same adjective is a Romanian specificity. Some authors underline the equivalence of PA adverbials and the underlying adverbial adjectives, the former 
being simply used to eventually boost the function of the latter. However, conceptual and functional differentiation is an issue that should be tackled by future investigation. For the moment, no thorough corpus-based study allows us to clearly distinguish between free variation of adverbial adjectives vs. semanticfunctional differentiation.

\section{Spanish (David Porcel Bueno)}

Spanish is the Romance language with the largest array of studies on PX adverbials in both synchrony, which was tackled first, and diachrony (see also Section 2 on the theoretical aspects discussed in the work on Spanish).

The most widespread approach in linguistic synchrony analyzes PX-patterns as phraseological units, which also include (adverbial or prepositional) locutions. PN and PA adverbials play a major role in Zuluaga (1980), Corpas Pastor (1997), and Ruiz Gurillo (1997; 2002), who study phraseological units in the broadest sense as frozen idiomatic expressions. In his seminal study on locutions, GarcíaPage $(2008,126)$ includes a large number of PA-patterns within the chapter on adverbial locutions: de lleno, de plano, de súbito, a menudo, en serio, por completo, a secas, en vano, de ordinario, de seguido, por descontado, etc. In the chapter dedicated to prepositional locutions, García-Page also mentions a relevant number of PAP-patterns (ib., 132): en lo referente a, a lo ancho de, en lo alto de, en lo relativo $a$, etc. These studies consider PA adverbials as a part of the Spanish locutional system. Consequently, they analyze PA adverbials regarding the features they share with locutions in general, e.g., frequency, lexicalization, idiomaticity, locational variation.

In line with this, the lexicography of locutions is a major issue. The most usual PA adverbials can therefore be found in phraseological dictionaries, such as in Seco/Andrés/Ramos (2005): a la tremenda, a la defensiva, a cubierto, a las claras, a seguido, de avanzada, de antiguo, de firme, en abstracto, en caliente, etc. (to a lesser extent, they can also be found in Cantera 2007 and Cejador/Carbonell/ Madronal 2008). On the other hand, there are dictionaries of locutions proper, such as Luque Toro (2009) for prepositional locutions and Penadés (2005) for adverbial locutions. There are also some PA/PN-patterns documented in the lexicographical work that is more interested in syntax and discourse (Náñez 1991; Slager 1997). Nevertheless, the most interesting work in this case is Fuentes Rodríguez (2009), which includes many PA adverbials: al contrario, en absoluto, en particular, en extremo, en definitiva, a lo sumo, en concreto, etc.

From the morphosyntactic point of view, one of the main goals in research has been to determine the syntactic structures that might become locutions. One 
of these structures is the prepositional group that underlies PA adverbials in, e.g., a lo lejos, en breve, entre tanto, a la larga, a lo ancho, etc. (García-Page, 2007). Contreras (2004) refers to processes of "immobilization" and grammaticalization. One such process is the adverbialization of the patterns " $a+$ nominal” (Martinez López 1999) and “de + nominal” (Martínez/Jørgensen 2013). Some PA-patterns have been studied exhaustively, for instance, a lo mejor, which has been analyzed with regard to the use of the subjunctive (Wasa 2002) or in relation to the use of quizá and seguramente (Barrios Sabator 2015). Marcos Sánchez (2005) studied particulary the PA adverbial por lo visto. Moreover, the PN adverbials por suerte (Meléndez Quero 2013) and en plan aroused great interest in pragmatic and discourse linguistic studies (Jørgensen 2009; Méndez Orense 2016; Català/Perdomo 2017; Rodríguez Lage 2017). From a wider perspective, Català Guitart (2005) has undertaken the construction of an electronic dictionary of compound adverbs. The basic form of these adverbs or generalized adverbs, Prep + Det $+\mathrm{N}+$ Modif, has allowed the defining of 16 formal classes, following the syntactic classification offered by Maurice Gross for French adverbs. Their syntactic and semantic properties have been established and described in binary matrixes (Penadés 2012; Martínez/Jørgensen 2013).

Both prescriptive and descriptive grammars have studied PA-patterns. The Nueva Gramática de la lengua española (RAE 2009, 2391) shows that it is one of the most productive schemes, offering a long list of adverbial locutions made of one preposition and one singular adjective (feminine or masculine): a diario, $a$ menudo, de seguida, de última, en picado, de pasada, etc. On the other hand, it highlights those PA-patterns that are made of one feminine plural adjective (with or without an article) since they represent a higher level of idiomatic fixedness (ib., 2391s.): a ciegas, a solas, a secas, de oídas, a las bravas, a la ligera, a la libre, etc. The Gramática descriptiva de la lengua española (Pavón 1999, 614) also discusses the remarkable productivity of those patterns and reveals that the PA-pattern represents a fundamental base for the creation of adverbial locutions.

From a diachronic point of view, Lapesa (1992 [1981], 79) drew attention to the importance that these phraseological units would probably have for the composition of the future Diccionario histórico de la lengua española, not only because of their pluriverbal form, but also because of their idiomatic character. Before that time, only partial interest had been dedicated to PX adverbials in Spanish (Skelton 1971). Little by little, first studies dealing with some historical aspects of locutions appeared (Martín Zorraquino 2002; Pons/Ruíz 2001), but the starting point of mainstream research on the diachrony of locutions, named "fraseología histórica”, was Echenique (2003): 


\begin{abstract}
“a la hora de analizar las unidades fraseológicas, nos enfrentamos a ellas de la misma manera que a un texto salido del pasado de la propia lengua, en el que la sintaxis se ha vuelto rígida, con el consiguiente bloqueo de los principios de percepción y reformulación en su sentido gramatical" (ib., 546).
\end{abstract}

It is noteworthy that Echenique and her group of researchers not only aimed at studying the history of Spanish locutions, but also claimed the relevance of crosslinguistic comparison (Echenique 2008a; 2011). In line with this, some Old and Middle Spanish PA-patterns have been compared to other languages: SpanishCatalan-Aragonese (Vicente Llavata, 2008a; 2008b; 2013; Porcel Bueno 2015; Pla/Vicente 2017) and Spanish-Portuguese (Ricós 2006; 2008b). However, most work was dedicated to Old (medieval) Spanish itself, especially in the field of legal and notarial texts (García Valle 2006; 2008a; 2008b; 2008c). It has been shown that some present-day PX adverbials have originated in this tradition (García Valle 2010a; 2010b). This supports the hypothesis of a tradition of using PXpatterns that is split into an oral-informal and a written-educated branch (Hummel 2019a; 2019b).

Some PA adverbials have been subject to thorough monographic analyses. The coordinated locutions a diestro y siniestro, a tuerto e a derecho, a tontas y a locas, have been analyzed by Ricós (2008a). The same author also tackles the patterns "preposition + idiomatic item" (a osadas, a reculas, a hotas, a sabiendas) and one PA-pattern proper "preposition + article + adjective" (a la callada, a la deshilada, a la sorda) (Ricós 2012).

Other PA adverbials have been taken under scrutiny from a diachronic morphosyntactic perspective as members of the general PX-pattern (Martínez López, 2007). Rodríguez Molina (2014) suggests a semantic classification of adverbials and locutions. Ortiz Ciscomani (2014) studies modal adverbial locutions belonging to the pattern "preposition $a+$ adjective ending in - $a s$ ", for instance $a$ ciegas. The same author analyzes the development from adjective to adverbial locution (Ortiz Ciscomani 2017). According to Ocampo (2006a; 2006b) this process is obvious in the case of the adjectives claro and bueno. Ocampo describes the process in terms of discoursivization, not grammaticalization, which means that the PApatterns become specialized for one or more functions in discourse. This tendency has also been observed by Hummel (2019a; 2019b) for Sp. fijo and Fr. vrai, without however excluding the possibility of an original equivalence between the adverbial adjectives and the corresponding PA adverbials (cf. Lavale-Ortiz, in press). The process of grammaticalization has been studied by Álvarez-Prendes (2018) in relation to en serio.

In her work on grammatical words, Espinosa Elorza (2010) also involves the adverbials de/por cierto, a tuerto and de mancomún. In the same vein, Espinosa Elorza (2012) observes the development of discourse functions of the PA-patterns 
a lo mejor and de seguro during the 19th century. Focusing on spatial relations, Octavio de Toledo (2016) tackles some PA adverbials such as a lo largo, de lo alto de, en lo hondo, a par de, al parejo, en el derecho, al igual, etc. Other patterns have undergone a more detailed diachronic analysis. This is the case for por cierto, which has been analyzed together with other epistemic items from the point of view of a discourse function (Villar Díaz 2013). The PA adverbials al justo and al cabal appear as variants in the diachronic study by Gerhalter (in press) on justo/ justamente, cabal/cabalmente, amongst others. In sum, the development of discourse functions in the modern language epoch seems to be a major issue in the diachrony of PX adverbials.

In view of an adequate representation in the still to be completed Nuevo diccionario histórico del español, Suárez Hernández (2014) has taken a lo mejor under scrutiny (cf. also Pérez-Salazar 2013). Echenique (2008b) tackles the historical lexicography of adverbial locutions in the database of DIAFRAES (Diacronía Fraseológica del Español) - in ongoing development - with many PA adverbials used in medieval and classical Spanish. As can be seen, many PX-patterns have been analyzed in diachronic lexicography. Satorre Grau (2008) collects adverbial locutions in the lexicographic work of the Golden Ages. In the same vein, Quilis Merín (2008) studies the existence and consolidation of adverbial locutions from Nebrija to Francocini. Álvarez Vives (2010) dedicates a paper to the locutions in the lexicography of Nicolas Mez de Braidenbach, as well as in the dictionaries by Vicente Salvá y Esteban Pichardo (Âlvarez Vives 2013). The grammaticographic tradition itself has been analyzed in the seminal work of Gómez Asencio (2003).

The study on so-called prepositional locutions is as important as the study on adverbial locutions discussed above. This is due to the fact that many PXPpatterns are built upon an adjective. From a diachronic point of view, Codita (2011; 2012; 2013; 2014; 2015) analyzes the binary pattern "P + noun" and the complex pattern " $\mathrm{P}+$ noun $+\mathrm{P}$ " in legal sources published between the 13 th and the 15th century. Porcel Bueno (2015; 2016a; 2016b; 2017a; 2017b) explores the occurrence and the development of complex PXP-patterns from the 13th to the 16th century. Vicente Llavata (2011) studies the prepositional locutions in the work of the Marqués de Santillana, one of the most renowned authors of the 15th century. PX-patterns and PXP-patterns can also be found in Ricós (2016) and García Valle/Ricós (2017), especially in medieval chronicles, both studies including a comparison with Galician and Portuguese. Locutions such as a fin de have undergone a detailed analysis in diachrony (Carrete 2016) and synchrony (Pavón 2013).

From a synchronic perspective, the number of studies on prepositional locutions is very high. From a phraseological point of view, Montoro del Arco's papers 
(2006; 2008) are fundamental. The author makes mention, among other issues, of some of the factors that need to be given so that these PXP-patterns can be considered prepositional locutions (Montoro del Arco 2006, 183s.): the PXP-pattern must be equivalent (semantically and formally) to one preposition, the locution has to finish with a preposition (XP-pattern or PXP-pattern), the locution has to connect two elements from a functional point of view, and the second element has to be a nominal structure. These "pruebas de funcionamiento preposicional" are widened by Cifuentes (2003, 115-123), who increases the number of "pruebas" to 22 , relating it to the theory of grammaticalization.

There has also been research on other morphosyntactic features of PXP-patterns. Ueda (1990) offers a formal, semantic, and syntactic characterization of what he calls "frases prepositivas" and establishes the levels of grammaticalization. Kazumi (1997) points to two groups of prepositional locutions: grammaticalized prepositional idioms, whose core has lost its original meaning (de cara $a$, a partir de, etc.) and others which are productive in determined structures (en armonía con, en solidaridad con, etc.). More recently, Satorre (2017) dedicates his work to the grammaticalization processes in the development of prepositional locutions at the levels of real development in diachrony and possible creation in the future. Moreover, Jiménez Juliá $(2017,91)$ defends the fully grammatical character, not the phraseological, of this pattern and he considers that so-called prepositional locutions "siguen modelos constructivos tan productivos como los de las estructuras sintácticas libres”.

As we can see, the attempts to classify PXP-patterns are not easy due to a wide range of linguistic criteria. In spite of this, Santos Río (2003a) has proposed a classification of prepositional locutions that distinguish them from what he calls prepositional pseudolocutions (Santos Río 2004). In an analogous way, Waluch de la Torre (2012), following Bosque's hypotheses (1997), presents the main terms and notions related to the phenomenon of prepositional sequences (por bajo, de sobre, en contra, en según, con hasta, etc.), which are frequently mistaken for idioms and correlating conjunctions. At times, the study on prepositional locutions has been carried out from a cognitive linguistic perspective, focusing on semantic aspects related to metaphor and metonymy (Insausti 2018), even comparing Spanish and Italian, as in Bartens/Granvik (2012).

As in the case of adverbial locutions, there are lexical repertoires specialized in prepositional patterns that include a high number of PAP-patterns, albeit not restricted to adverbial functions (Slager 1997; Náñez 2001; Santos Río 2003b). Other lists have been suggested by Luque (2009) and Briz/Pons/Portolés (DPDE). Additionally, from the perspective of historical lexicography, Santos Río (2001) analyzes prepositional locutions in the dictionaries of the Spanish Real Academy, and Quilis Merín (2016) takes the lexicography of the Golden Ages under scrutiny, 
especially in the work of Sebastián de Covarrubias. The papers of Gómez Asencio (2008a; 2008b) represent the most complete synthesis of grammaticographic study on prepositional locutions.

Lastly, a still increasing number of papers deal with locutions in Spanish dialects (González Aguiar 2007). The combination of historical "phraseology” and dialectology has been particularly developed in the Canary Islands (Cáceres Lorenzo 1992; Ortega/González Aguiar 2017). Adverbial locutions (Hernández Sánchez 1992) and prepositional locutions (Ojeda 2014) have also been studied in the Spanish of Andalusia, more specifically the educated registers ("habla culta") of Seville. In the study by Fitch Romero (2018) on the colloquial locutions of the Spanish spoken in Mexico, we can find some examples of PA-patterns: a (sus) anchas, a la despreocupé, a las caiditas, a la mera hora, a lo bestia, a medio palo, de puro (panzazo), de volada, por lo bajines, por lo bajini, etc. From a similar perspective, Mora (in press) studies some PPA-patterns of Mexican Spanish (de a gratis, de a jodido, de a feo, de adrede, etc.).

\section{Conclusion}

Although there is abundant evidence for the relevance of PA-patterns in Romance, they have not been subject to a monographic study. PA-patterns seem to have been very productive until the 16th-17th centuries, when efforts of standardization started to marginalize them. Since modern studies tend to view the past with present-day eyes, the marginal and rather lexicalized status of PA adverbials in modern standards of Romance has induced research to underestimate their relevance in diachrony. Consequently, PX adverbials have mainly been considered by lexicological and lexicographic approaches. In addition, the fact that PA adverbials were scarcely used in Latin, but abruptly and abundantly surfaced in early Romance provides evidence for their belonging to the oral tradition of Romance. Hence, the observation of written language may have further contributed to the neglect of PA adverbials. In particular, the role of mainstream analyticization in the Latin-Romance tradition has never been discussed for this type of adverbial. The systematic study of their role in long-term diachrony is therefore a major desideratum in research. Such a study should include linguistic variation, especially the use of PA adverbials in more orality- or more literacy-based texts and discourses.

As shown by the bibliography, PN and PP adverbials clearly prevail and possibly played a pioneering role in diachrony. For this reason, isolating PA-patterns from the bulk of PX-patterns, entails a relevant methodological bias. On the other hand, there is evidence for the development of PA adverbials from baseline ad- 
verbial adjectives (Type A, e.g., Sp. hablar claro), which prevailed in the oral tradition. Hence, this approach may help to better understand the role of manner adverbials in the diachrony of spoken language. This does not mean that PA adverbials belong to spoken language only. Studies on Old Spanish clearly show that the PA-pattern played an important role in linguistic elaboration, also in very formal types of text. In turn, however, this fact does not mean that the productive rule itself has not to be sought in the development of spoken Latin and Romance.

\section{References}

Alberti, Leon Battista, La Grammatichetta Vaticana, in: Grayson, Cecil (ed.), Leon Battista Alberti. La prima grammatica della lingua volgare. La Grammatichetta Vaticana Cod. Vat. Reg. Lat. 1370, Bologna, Commissione per i Testi di Lingua, 1964, 1-62.

Alessio, Giovanni, Grammatica storica francese, vol. 2: Morfologia, Bari, Leonardo da Vinci, 1955. Almeida, Maria Lucia Leitão, Preposições, advérbios e conjunções: um estudo de reanálise, dissertação de mestrado, Rio de Janeiro, Universidade Federal do Rio de Janeiro, 1984.

Álvarez Vives, Vicente, Apuntes de fraseología histórica: las locuciones adverbiales en el "Diccionario muy copioso de la lengua española y alemana[...]" de Nicolas Mez de Braidenbach (1670), in: Encinas Manterola, María Teresa, et al. (edd.), Ars longa: diez años de AJIHLE, vol. 2, Buenos Aires, Voces del Sur, 2010, 515-530.

Álvarez Vives, Vicente, Estudio fraseológico contrastivo de las locuciones adverbiales en los diccionarios de Vicente Salvá y de Esteban Pichardo: hacia una fraseología histórica del español en la lexicografía del siglo XIX, Valencia, Universitat de València, 2013.

Álvarez-Prendes, Emma, Polyfonctionnalité adverbiale, grammaticalisation et subjectivation: le cas de "sérieusement", "seriamente" et "en serio", Zeitschrift für romanische Philologie 134 (2018), 471-486.

Andrade, Queli Cristina de, Ordenação das locuções adverbiais de tempo em editoriais, dissertação de mestrado, Rio de Janeiro, Universidade Federal do Rio de Janeiro, 2005.

Araújo-Vale, Oto, Expressões cristalizadas. Transparência e opacidade, Signótica 11 (1999), 163172, DOI: <10.5216/sig.v11i1.7282〉.

Araújo-Vale, Oto, Expressões cristalizadas do Português do Brasil: uma proposta de tipologia, tese de doutoramento, Araraquara, Universidade Estadual Paulista, 2001.

Arnauld, Antoine/Lancelot, Claude, Grammaire générale et raisonnée, Bruxelles/New York/ Hildesheim, Olms, 1973 [1660/1676].

Azevedo, José Carlos, Gramática Houaiss da língua portuguesa, São Paolo, Publifolha, 2018.

Badia i Margarit, Antonio María, Los complementos pronominalo-adverbiales derivados de "ibi" e "inde" en la Península Ibérica, Madrid, Consejo Superior de Investigaciones Científicas, 1947.

Badia i Margarit, Antonio María, Sobre "ibi" e "inde" en las lenguas de la Península Ibérica, Revista de Filología Española 35 (1951), 62-74.

Badia i Margarit, Antonio María, Gramática catalana, 2 vol., Madrid, Gredos, 1962.

Bally, Charles, Linguistique générale et linguistique française, Berne, Franke, ${ }^{4} 1965$ [1932]. 
Baptista, Jorge/Fernandes Graça/Correia, Anabela, Léxico-gramática das frases fixas do portugués europeo. Breve presentación, Cadernos de Fraseoloxía Galega 7 (2005), 41-53.

Barbosa, Mariana Gonçalves, Gramaticalização de advérbios a partir de adjetivos: um estudo sobre adjetivos adverbializados, dissertação de mestrado, Rio de Janeiro, Universidade Federal do Rio de Janeiro, 2006.

Barrios Sabator, María José, Variabilidad del discurso oral: el caso de "seguramente". Un análisis comparativo con “quizá(s)” y “a lo mejor”, Verba Hispánica 23:1 (2015), 61-86, DOI: $\langle 10.4312 / v h .23 .1 .61-86\rangle$.

Bartens Adawonu, Angela/Granvik, Anton, Gramaticalización y lexicalización en la formación de locuciones preposicionales en español e italiano, in: Montero Cartelle, Emilio/Manzano Rovira, Carmen (edd.), Actas del VIII Congreso Internacional de Historia de la Lengua Española, vol. 2, Madrid, Arco Libros, 2012, 2029-2046.

Bassols de Climent, Mariano, Sintaxis latina, vol. 1, Madrid, Consejo Superior de Investigaciones Científicas, Patronato “Menéndez y Pelayo", 1967.

Bastian, Sabine/Hammer, Françoise, "Bref” et "en somme" marqueurs de glose, in: Steuckardt, Agnès/Niklas-Salminen, Aïno (edd.), Les marqueurs de glose, Aix-en-Provence, Publications de l'Université de Provence, 2005, 171-188.

Bechara, Evanildo, Moderna gramática portuguesa, Edição revista e ampliada, Rio de Janeiro, Lucerna, 2001.

Beckmann, Gustav Adolf, Die Nachfolgekonstruktionen des instrumentalen Ablativs im Spätlatein und im Französischen, Tübingen, Niemeyer, 1963.

Bembo, Pietro, Prose della volgar lingua, in: Dionisotti, Carlo (ed.), Prose e rime di Pietro Bembo, Torino, UTET, ${ }^{2} 1966$ [1525], 73-309.

Berruto, Gaetano/Cerruti, Lorenzo, La linguistica. Un corso introduttivo, Turin, UTET Università, 2011.

Blumenthal, Peter, D'une encyclopédie à l'autre. L'ascension des locutions prépositionnelles, Langages 206:2 (2017), 123-138.

Bojílova Tchobánova, lovka, Os somatismos máis frecuentes na fraseoloxía portuguesa, Cadernos de Fraseoloxía Galega 11 (2009), 65-79.

Bosque Muñoz, Ignacio, Preposición tras preposición, in: Dorta Luis, Josefa/Almeida Suárez, Manuel (edd.), Contribuciones al estudio de la lingüística hispánica. Homenaje al profesor Ramón Trujillo, Madrid, Montesinos, 1997, 133-156.

Bourciez, Édouard, Éléments de linguistique romane, Paris, Klincksieck, 1967 [1910].

Bruguera, Jordi, La locució prepositiva "de part", el present històric i el perfect perifràstic en la Crònica de Jaume I, in: Miscel-lània Pere Bohigas, vol. 1, Barcelona, Abadia de Montserrat, 1981, 27-42.

Brunot, Ferdinand, Histoire de la langue française des origines à nos jours, 13 vol., Paris, Colin, 1905-1979.

Brunot, Ferdinand, La pensée et la langue, Paris, Masson, 1922.

Cabré i Monné, Teresa, Sobre les preposicions febles en català. A-EN, tesis doctoral, Barcelona, Universitat Autònoma de Barcelona, 1980.

Cáceres Lorenzo, María Teresa, Expresiones adverbiales en el español de Canarias, La Laguna, Instituto de Estudios Canarios, 1992.

Caddéo, Sandrine, Rôle et fonctionnement d'“en particulier" dans les séquences glosantes, in: Steuckardt, Agnès/Niklas-Salminen, Aïno (edd.), Les marqueurs de glose, Aix-en-Provence, Publications de l'Université de Provence, 2005, 189-202. 
Camprubí, Michel, Les preposicions en els complements circumstancials de lloc i de tems a través del corpus "Atlas català", in: Badia i Margarit, Antoni María/Associació Internacional de Llengua i Literatura Catalanes (edd.), Estudis de llengua i literatura catalanes, Miscel-lània, vol. 9, Barcelona, Abadia de Montserrat, 1984, 65-80.

Cantera Ortiz de Urbina, Jesús/Gomis Blanco, Pedro, Diccionario de fraseología española: locuciones, idiomatismos, modismos y frases hechas usuales en español, Madrid, Abada, 2007.

Capin, Daniéla, "Petit" et "peu” en ancien et moyen français, Verbum 29:3-4 (2007), 287-303.

Capin, Daniéla, Évolution d'un quantifieur-intensifieur: "petit" depuis l'ancien français jusqu'au français classique, in: Combettes, Bernard, et al. (edd.), Le changement en français, Bern et al., Lang, 2010, 93-109.

Carneiro da Silva, Euclides, Dicionário de locuções da língua portuguesa, Rio de Janeiro, Bloch, 1975.

Carrete Montaña, José Ricardo, “A fin de”: del espacio a la finalidad, Res diachronicae 14:1 (2016), 13-26.

Casanova, Emili, Sobre la construcció prepositiva $\mathrm{N}+\mathrm{P} 1+\mathrm{C}+\mathrm{P} 2+\mathrm{T}$ en català antic, in: Badia $\mathrm{i}$ Margarit, Antoni María/Associació Internacional de Llengua i Literatura Catalanes (edd.), Estudis de llengua i literatura catalanes, Miscel·lània, vol. 9, Barcelona, Abadia de Montserrat, 1984, 43-63.

Castilho, Ataliba Teixeira de, Problema da gramaticalização das preposições no projeto "Para a história do português brasileiro", Estudos lingüísticos 33 (2004), 982-988.

Castilho, Ataliba Teixeira de, Nova gramática do português brasileiro, São Paulo, Contexto, 2010.

Català Guitart, Dolors, Les adverbes composés. Approches contrastives en linguistique appliquée, tesis doctoral, Barcelona, Universitat Autònoma de Barcelona, 2005.

Català Pérez, Manuela/Perdomo Carmona, Marialys, La innovación léxica de "en plan" como fórmula expresiva de los jóvenes universitarios españoles: aproximación a sus valores de uso tradicional y actual, Tonos digital: Revista de estudios filológicos 33 (2017), 1-19.

Cejador y Frauca, Julio/Carbonell, Delfín/Madroñal Durán, Abraham, Diccionario fraseológico del Siglo de Oro: fraseología o estilística castellana, Barcelona, Ediciones del Serbal, 2008.

Ceppellini, Vincenzo, Nuovo dizionario pratico di grammatica e linguistica, Novara, De Agostino, 1999.

Cezario, Maria Maura, A ordenação de locuções adverbiais de tempo em cartas jesuíticas dos séculos XVI e XVII, Signótica 28 (2016), 557-580, DOI: <https://doi.org/10.5216/sig. v28i2.35599>.

Cezario, Maria Maura/Castanheira, Dennis, Locuções adverbiais de tempo em cartas oficiais do século XIX: motivações para a ordenação, Revista Soletras 28 (2014), 41-59, DOI: <https:// doi.org/10.12957/soletras.2014.13356>.

Cezario, Maria Maura/llogti de Sá, Érika Cristine/Costa Nunes, Julia Oliveira, Ordenação de adverbiais temporais ou aspectuais, Transformar. Revista do CenPE/Fundação São José 3 (2005), 214-227.

Chircu, Adrian, Locuţiunile adverbiale de tipul: “de-a lungul, de-a gata, de-a binelea”, in: Pană Dindelegan, Gabriela (ed.), Limba română - stadiul actual al cercetării. Actele celui de-al 6 lea Colocviu al Catedrei de limba română (29-30 noiembrie 2006), Bucureşti, Editura Universităţii din Bucureşti, 2007, 67-75.

Chircu, Adrian, L'adverbe dans les langues romanes. Études étymologique, lexicale et morphologique, Cluj-Napoca, Casa Cărţii de Ştiinţă, 2008. 
Chircu, Adrian, Remarques sur les adjectifs adverbialisés en français et en roumain, Studii şi cercetări lingvistice 65 (2014), 177-187.

Chircu, Adrian, Un tipar locuţional adverbial în limba română veche: "pre larg, pre scurt, pre lesne”, in: Zafiu, Rodica/Nedelcu, Isabela (edd.), Variaţia lingvistică: probleme actuale. Actele celui de-al 14-lea Colocviu Internaţional al Departamentului de lingvistică (Bucureşti, 28-29 noiembrie 2014), vol. 1, Bucureşti, Editura Universităţii din Bucureşti, 2015, 11-19.

Chircu-Buftea, Adrian, Dinamica adverbului românesc. leri şi azi, Cluj-Napoca, Casa Cărţii de Ştiinţă, 2011.

Cifuentes Honrubia, José Luis, Locuciones prepositivas: sobre la gramaticalización preposicional en español, Alicante, Universidad de Alicante, 2003.

Ciobanu, Fulvia, Valorile prepoziţiilor în construcţie cu adverbele, in: Graur, Alexandru/Byck, Jacques (edd.), Studii de gramatică, vol. 3, Bucureşti, Editura Academiei Române, 1961, 43-66.

Ciompec, Georgeta, Morfosintaxa adverbului românesc. Sincronie şi diacronie, Bucureşti, Editura Ştiinţifică şi Enciclopedică, 1985.

Codita, Viorica, Estudio comparativo de las locuciones prepositivas en "Calila e Dimna" y "El Conde Lucanor". En torno a las unidades con "en" y "por", in: Carmona Yanes, Elena/Rey Quesada, Santiago del (edd.), Id est, loquendi peritia: aportaciones a la lingüística diacrónica de los jóvenes investigadores de Historiografía e Historia, Sevilla, Universidad de Sevilla, 2011, 203-214.

Codita, Viorica, Observaciones acerca de las locuciones prepositivas en la "Primera Partida", in: Montero Cartelle, Emilio/Manzano Rovira, Carmen (edd.), Actas del VIII Congreso Internacional de Historia de la Lengua Española, vol. 1, Madrid, Arco Libros, 2012, 735-748.

Codita, Viorica, Sobre los usos de las locuciones prepositivas en textos del siglo XIII, in: Casanova, Emili/Calvo Rigual, Cesáreo (edd.), Actas del XXVI Congreso Internacional de Lingüística y de Filología Románicas, vol. 4, 2013, 101-112.

Codita, Viorica, Algunas consideraciones sobre las locuciones prepositivas en castellano antiguo, en Álvarez Vives, Vicente/Diez del Corral Areta, Elena/Reynaud Oudot, Natacha (edd.), Dándole cuerda al reloj: ampliando perspectivas en lingüística histórica de la lengua española, Valencia, Tirant lo Blanch, 2014, 369-389.

Codita, Viorica, Agrupaciones de preposiciones desde el punto de vista diacrónico y su (no) relación con las locuciones prepositivas, in: García Martín, José María/Bastardín Candón, Teresa/Rivas Zancarrón, Manuel (edd.), Actas del IX Congreso Internacional de Historia de la Lengua Española, Madrid, Arco Libros, 2015, 701-716.

Company Company, Concepción (ed.), Sintaxis histórica de la lengua española. Tercera parte: Adverbios, preposiciones y conjunciones. Relaciones interoracionales, vol. 1, México, Universidad Nacional Autónoma de México/Fondo de Cultura Económica, 2014.

Consales, Ilde, Invariabili, in: Antonelli, Giuseppe/Motolese, Matteo/Tomasin, Lorenzo (edd.), Storia dell'italiano scritto, vol. 4: Grammatiche, Roma, Carocci, 2018, 323-356.

Contreras, Joan Miquel, Los complejos preposicionales en las lenguas románicas, in: Zabala Unzalu, Igore/Pérez Gaztelu, Elixabete/Sole, Llüisa Gràcia (edd.), Las fronteras de la composición en las lenguas románicas y el vasco, San Sebastián, Universidad de Deusto, 2004, 261-280.

Corpas Pastor, Gloria, Manual de fraseología española, Madrid, Gredos, 1997.

Costa, João, O advérbio em português europeu, Lisboa, Colibri, 2008.

Costa, Sônia Bastos Borba, Adverbiais espaciais e temporais do português: indícios diacrônicos de gramaticalização, tese de doutorado, Salvador, Universidade Federal da Bahia, 2003. 
Costa, Sônia Bastos Borba, Fontes lexicais de adverbiais espaciais e temporais portugueses, in: Oliveira, Klebson/Cunha e Souza, Hirão/Soledade, Juliana (edd.), Do português arcaico ao português brasileiro: outras histórias, Salvador, EDUFSA, 2009, 77-99.

Costa, Sônia Bastos Borba, Adverbiais espaciais e temporais portugueses: trajetos léxico-semânticos, in: Lobo, Tânia, et al. (edd.), Rosae: lingüística histórica, história das línguas e outras históricas, Salvador, EDUFBA, 2012, 417-440.

Croft, William, Radical Construction Grammar, Oxford, Oxford University Press, 2001.

Cruschina, Silvio/Ledgeway, Adam, The structure of the clause, in: Ledgeway, Adam/Maiden, Martin (edd.), The Oxford Guide to the Romance Languages, Oxford, Oxford University Press, 2016, 556-574.

Cunha, Celso/Cintra, Lindley, Nova gramática do português contemporâneo, Lisboa, João Sáda Costa, 1984.

D’Achille, Paolo, Architettura dell'italiano di oggi e linee di tendenza, in: Lubello, Sergio (ed.), Manuale di linguistica italiana, Berlin/Boston, De Gruyter, 2016, 165-189.

Damourette, Jacques/Pichon, Éduard, Des mots à la pensée. Essai de grammaire de la langue française, 3 vol., Paris, Éditions d’Artrey, 1911-1933.

Dardano, Maurizio/Trifone, Pietro, La nuova grammatica della lingua italiana, Bologna, Zanichelli, 1997.

Dardano, Maurizio/Frenguelli, Gianluca/Colella, Gianluca, Gli “avverbi di certezza” in italiano antico: sintassi e funzioni pragmatico-discorsive, unpublished paper presented at the XXVIIIe Congrès international de linguistique et de philologie romanes (Rome, 18-23 juillet 2016).

Darmesteter, Arsène, Traité de la formation des mots composés dans la langue française comparée aux autres langues romanes et au latin, Paris, Champion, ${ }^{2} 1967$ [1893].

Delbecque, Nicole, De la funcionalidad del clítico femenino plural en locuciones verbales, Revista de Filología Románica 14 (1997), 211-224.

Demattio, Fortunato, Origine, formazione ed elementi della lingua italiana, Innsbruck, Wagner, ${ }^{2} 1876$.

Densusianu, Ovid, Histoire de la langue roumaine, ediţie critică şi note de Valeriu Rusu, prefaţă de Boris Cazacu, Bucureşti, Editura “Grai şi Suflet - Cultura Naţională”, 1997.

Devoto, Giacomo, Storia della lingua di Roma, Bologna, Cappelli, 1987 [1940].

Di Castelli, Giovanni Tomaso, Nuova e perfetta grammatica reggia italiana e tedesca, Leipzig, Gleditsch, 1748.

Diémoz, Federica, Monter en haut et descendre en bas: les verbes de déplacement dans les parlers francoprovençaux et dans les langues romanes voisines, in: Chauveau, Jean-Paul/ Barbato, Marcello/Fernández-Ordoñez, Inés (edd.), Actes du XXVII Congrès internacional de linguistique et de philologie romanes (Nancy 15-20 juillet 2013), section 8, linguistique variationnelle, dialectologie et sociolinguistique, Nancy, ATILF, 2016, 93-103, <http://www. atilf.fr/cilpr2013/actes/section-8.html>.

Diez, Friedrich, Grammatik der romanischen Sprachen, Bonn, Weber, ${ }^{5} 1882$.

Dionisotti $\rightarrow$ Bembo.

DPDE = Briz Gómez, Antonio/Pons Bordería, Salvador/Portolés Lázaro, José, Diccionario de partículas discursivas del español, 2008, 〈www.dpde.es〉.

Dragomirescu, Gheorghe N., Locuţiunile adverbiale, Limbă şi literatură 5 (1961), 59-67.

Echenique Elizondo, María Teresa, Pautas para el estudio histórico de las unidades fraseológicas, in: Girón Alconchel, José Luis/Herrero Ruiz de Loizaga, F. Javier/Iglesias Recuero, Silvia/Narbona Jiménez, Antonio (edd.), Estudios ofrecidos al profesor José Jesús de Bustos Tovar, vol. 1, Madrid, Universidad Complutense, 2003, 545-560. 
Echenique Elizondo, María Teresa, Algunas notas sobre latín y romance en la fraseología hispánica medieval, in: Wright, Roger (ed.), Latin vulgaire - latin tardif VIII. Actes du VIII Colloque international sur le latin vulgaire et tardif, Oxford, St. Catherine's College, 2008, 540-547 $(=2008 \mathrm{a})$.

Echenique Elizondo, María Teresa, Notas de sintaxis histórica en el marco del corpus de diacronía fraseológica del español (DIAFRAES), in: Stark, Elisabeth/Schmidt-Riese, Roland/Stoll, Eva (edd.), Romanische Syntax im Wandel, Tübingen, Narr, 2008, 387-397 (= 2008b).

Echenique Elizondo, María Teresa, Fraseología vasco-románica. Acotaciones para su estudio, Oihenart. Cuadernos de lengua y literatura 26 (2011), 145-162.

Echenique Elizondo, María Teresa/Martínez Alcalde, María José/Sánchez Méndez, Juan Pedro/ Pla Colomer, Francisco P. (edd.), Fraseología española. Diacronía y codificación, Madrid, CSIC, 2016.

Echenique Elizondo, María Teresa/Martínez Alcalde, María José/Pla Colomer, Francisco P., La fraseología a través de la historia de la lengua española y su historiografía, Valencia, Tirant humanidades, 2017.

Elcock, William, The Romance Languages, London, Faber/Faber, 1960.

Ernst, Gerhard/Gleßgen, Martin-Dietrich/Schmitt, Christian/Schweickard, Wolfgang (edd.), Romanische Sprachgeschichte / Histoire linguistique de la Romania. Ein internationales Handbuch zur Geschichte der romanischen Sprachen / Manuel historique d'histoire linguistique de la Romania, 3 vol., Berlin/New York, De Gruyter, 2003-2008.

Espinal, María Teresa, Diccionari de sinònims de frases fetes, Barcelona, Universitat Autònoma de Barcelona, 2004.

Espinosa Elorza, Rosa María, Procesos de formación y cambio en las llamadas "palabras gramaticales", San Millán de la Cogolla, Cilengua, 2010.

Espinosa Elorza, Rosa María, Cambios sintácticos en el sigloXIX, in: Ramírez Luengo, José Luis (ed.), Por sendas ignoradas. Estudios sobre el español en el siglo XIX, Lugo, Axac, 2012, 61-74.

Fagard, Benjamin, Prépositions et locutions prépositionnelles : un sémantisme comparable?, Langages 173 (2009), 95-113.

Fagard, Benjamin, De "ante" à "devant" et "avant": différenciation sémantique dans l'évolution des langues romanes, Langages 188 (2012), 111-131 (= 2012a).

Fagard, Benjamin, Prépositions et locutions prépositionnelles. La question du renouvellement grammatical, Travaux de linguistique 64:1 (2012), 161-189 (= 2012b).

Fagard, Benjamin/Mardale, Alexandru, The pace of grammaticalization and the evolution of prepositional systems. Data from Romance, Folia linguistica 46 (2012), 303-340.

Fagard, Benjamin/Sarda, Laure, From local adverbials to discourse markers. Three case studies in the diachrony of French, in: Sarda, Laure/Carter-Thomas, Shirley/Fagard, Benjamin/ Charolles, Benjamin (edd.), Adverbials in Use. From Predicative to Discourse Functions, Louvain-la-Neuve, Presses universitaires de Louvain, 2014, 203-238.

Féron, Corinne, “Pour vrai”, "pour certain”, "pour sûr”...: formation et évolution d'adverbiaux en “pour”, Langue française 156:4 (2007), 61-75.

Fitch Romero, Roxana, Las locuciones coloquiales del español de México: inventario y criterios de clasificación, tesis doctoral, Barcelona, Universitat Autònoma de Barcelona, 2018.

Fortunio, Gian Francesco, Regole grammaticali della volgar lingua, di messer Francesco Fortunio novellamente reviste, et con somma diligentia emendate, Vinegia, Bindoni e Pasini, 1539.

Franciosini, Lorenzo, Grammatica spagnuola ed italiana, Roma, R. Cam. Apost, ${ }^{2} 1638$ [1624]. Frâncu, Constantin, Gramatica limbii române vechi: 1521-1780, vol. 39, Iaşi, Demiurg, 2009. 
Fuentes Rodríguez, Catalina, Diccionario de conectores y operadores del español, Madrid, Arco Libros, 2009.

Fuster Ortuño, María Ángeles/Sánchez-López, Elena, La fraseologia vista des d'una doble perspectiva: sincrònica i diacrònica, eHumanista/VITRA 2 (2012), 185-201, <https://www.ehumanista.ucsb.edu/sites/secure.Isit.ucsb.edu.span.d7_eh/files/sitefiles/ivitra/volume2/ 8\%20MAngels-Elena\%20185-201.pdf> .

Fuster Ortuño, María Ángeles/Sánchez-López, Elena, Estudi de les unitats fraseològiques de la tercera esfera des d'una perspectiva diacrònica, Caplletra: Revista internacional de filologia 56 (2014), 243-267.

García Benito, Ana Belén, Diccionario de expresiones idiomáticas español-portugués, Mérida, Gabinete de Iniciativas Transfronterizas-Junta de Extremadura, 2006.

García Benito, Ana Belén, Locuciones con clítico de objeto directo en portugués, Limite: Revista de estudios portugueses y de la Lusofonía 3 (2009), 7-25.

García-Hernández, Benjamín, Nombre y concepto de "latín vulgar”. "Vulgus”, “uulgo” y “uulgaris". Generalidad y diversidad, in: García Leal, Alfonso/Prieto Entrialgo, Clara Elena (edd.), Latin vulgaire - latin tardif XI: XI Congreso Internacional sobre el Latin Vulgar y Tardío, Hildesheim, Olms, 2017, 62-85.

García Valle, Adela, Una primera aproximación al estudio de la formulación jurídica medieval de la Edad Media desde la perspectiva de la fraseología, in: de Bustos Tovar, José Jesús/Girón Alconchel, José Luis (edd.), Actas del VI Congreso Internacional de Historia de la Lengua Española, Madrid, Arco Libros, 2006, 1385-1400.

García Valle, Adela, La Fraseología histórica en el Fuero de Valfermoso de las Monjas: fórmulas jurídicas y locuciones adverbiales, in: Martínez Alcalde, María José/Satorre Grau, Javier (edd.), Actas del Simposio Internacional “El legado de Rafael Lapesa" (Valencia, 1908-Madrid 2001), Valencia, Biblioteca Valencia, Sociedad Estatal de Conmemoraciones Culturales, 2008, 227-234 (= 2008a).

García Valle, Adela, Las locuciones adverbiales en la documentación notarial medieval, in: Company Company, Concepción/Moreno de Alba, José G. (edd.), Actas del VII Congreso Internacional de Historia de la Lengua Española, Madrid, Arco Libros, 2008, 593-612 $(=2008 \mathrm{~b})$.

García Valle, Adela, A propósito de la importancia de las locuciones adverbiales en el análisis de los textos medievales: algunas notas para la edición de textos jurídicos antiguos, in: Olza Moreno, Inés/Casado Velarde, Manuel/González Ruiz, Ramón (edd.), Actas del XXXVII Simposio Internacional de la Sociedad Española de Lingüística (SEL), Pamplona, Servicio de Publicaciones de la Universidad de Navarra, 2008, 195-206 (= 2008c).

García Valle, Adela, Locuciones adverbiales de ámbito jurídico: de los fueros medievales a su consolidación en la lengua, Revista de filología española 90 (2010), 137-171, DOI: <https:// doi.org/10.3989/rfe.2010.v90.i1.200> (= 2010a).

García Valle, Adela, Las locuciones adverbiales en la documentación notarial medieval, in: Company Company, Concepción/Moreno de Alba, José G. (ed.), Actas del VII Congreso Internacional de Historia de la Lengua Española, Madrid, Arco Libros, 2010, 593-611 $(=2010 \mathrm{~b})$

García Valle, Adela/Ricós Vidal, Amparo, La expresión de la causa a través de las combinaciones locucionales prepositivas medievales en las crónicas alfonsíes y en sus traducciones al gallego y al portugués, in: Echenique Elizondo, María Teresa/Martínez Alcalde, María José/ Pla Colomer, Francisco P., La fraseología a través de la historia de la lengua española y su historiografia, Valencia, Tirant humanidades, 2017, 87-111. 
García-Page Sánchez, Mario, Esquemas sintácticos de formación de locuciones adverbiales, Moenia. Revista lucense de lingüística \& literatura 13 (2007), 121-144, <http://hdl.handle. net/10347/6069>.

García-Page Sánchez, Mario, Introducción a la fraseología española. Estudio de las locuciones, Barcelona, Anthropos, 2008.

GALR = Guţu Romalo, Valeria, et al. (edd.), Gramatica limbii române, tiraj nou, revizuit, 2 vol., Bucureşti, Editura Academiei Române, 2008.

GBLR = Pană Dindelegan, Gabriela (edd.), Gramatica de bază a limbii române, ediţia a II-a, Bucureşti, Editura Univers Enciclopedic Gold, 2016.

Gerhalter, Katharina, Paradigmas y polifuncionalidad. La diacronía de "preciso/precisamente", "justo/justamente", "exacto/exactamente" y "cabal/cabalmente", Berlin, De Gruyter, in press.

Ginebra Serrabou, Jordi/Navarro Gómez, Pere, Revisió del tractament de les unitats fraseològiques en diccionaris catalans dels segles XVI, XVII i XVIII, in: Zimmermann, Marie-Claire/ Charlon, Anne (edd.), Actes del dotze Colloqui Internacional de Llengua i Literatura Catalanes, vol. 3, Barcelona, Publicacions de l'Abadia de Montserrat, 2003, 113-124.

$\mathrm{GLR}=$ Graur, Alexandru (ed.), Gramatica limbii române, 3 vol., Bucureşti, Editura Academiei Române, ${ }^{2} 1963$.

Gómez Asencio, José, De las locuciones adverbiales, ¿qué se hizo en la tradición gramatical española?, Interlingüística 14 (2003), 59-76.

Gómez Asencio, José, El tratamiento de lo que ahora se llama "locuciones prepositivas" en sesenta y cuatro gramáticas del español (1555-1930), Quaderns de filología. Estudis lingüístics 13 (2008), 39-103 (= 2008a).

Gómez Asencio, José, El tratamiento de lo que ahora se llama "locuciones prepositivas" en sesenta y cuatro gramáticas del español (1555-1930) [2], in: Maquieira Rodríguez, Marina/ Martínez Gavilán, María Dolores (edd.), Gramma-temas 3: España y Portugal en la tradición gramatical, León, Universidad de León, Centro de Estudios Metodológicos e Interdisciplinares, 2008, 75-104 (= 2008b).

González Aguiar, Isabel, La fraseología regional del español, Revista de Filología de la Universidad de La Laguna (Homenaje a Dr. D. Antonio Lorenzo Ramos) 25 (2007), 235-247.

GR = Pană Dindelegan, Gabriela (ed.), The Grammar of Romanian, Oxford, Oxford University Press, 2013.

Grandgent, Charles, Introducción al latín vulgar, Madrid, CSIC, 1963 [1907].

Grayson, Cecil (ed.), Leon Battista Alberti. La prima grammatica della lingua volgare. La Grammatichetta Vaticana Cod. Vat. Reg. Lat. 1370, Bologna, Commissione per i Testi di Lingua, 1964.

Grevisse, Maurice/Goosse, André, Le bon usage, Brussels, De Boeck, ${ }^{16} 2016$.

Griera, Antoni, Gramàtica històrica del català antic, Barcelona, Instituto Patxot, 1931.

Gross, Maurice, Grammaire transformationnelle du français (Syntaxe de l'adverbe), vol. 3, Paris, ASSTRIL, 1986.

Grossmann, Maria/Rainer, Franz, La formazione delle parole in italiano, Tübingen, Niemeyer, 2004.

Grundt, Lars-Otto, Études sur l'adjectif invarié en français, Bergen/Oslo/Tomsø, Universitetsforlaget, 1972.

Heise, Wilhelm, Zur historischen Syntax des adverbial gebrauchten Adjektivs im Französischen, Romanische Forschungen 31 (1912), 873-1038.

Hengeveld, Kees, Non-Verbal Predication. Theory, Typology, Diachrony, Berlin/New York, Mouton de Gruyter, 1992. 
Hengeveld, Kees/Rijkhoff, Jan/Siewierska, Anna, Parts-of-speech systems and word order, Journal of linguistics 40 (2004), 527-570.

Hengeveld, Kees/van Lier, Eva, An implicational map of parts of speech, Linguistic discovery 8 (2010), 129-156, DOI: <10.1349/PS1.1537-0852.A.348>.

Hernández Sánchez, José Agustín, Las locuciones adverbiales en el habla culta de Sevilla, Revista de Humanidades 3 (1992), 125-140.

Hofmann, Johann Baptist/Szantyr, Anton, Lateinische Syntax und Stilistik, mit dem allgemeinen Teil der lateinischen Grammatik, München, Beck, 1972.

Hummel, Martin, Attribution in Romance: reconstructing the oral and written tradition, Folia linguistica historica 34 (2013), 1-42.

Hummel, Martin, The adjective-adverb interface in Romance and English, in: Sleeman, Petra/Van de Velde, Freek/Perridon, Harry (edd.), Adjectives in Germanic and Romance, Amsterdam/ Philadelphia, Benjamins, 2014, 35-71 (= 2014a).

Hummel, Martin, Adjetivos adverbiales, in: Company, Concepción (ed.), Sintaxis histórica de la lengua española. Tercera parte: Adverbios, preposiciones y conjunciones. Relaciones interoracionales, tomo 1, México, Universidad Nacional Autónoma de México-Fondo de Cultura Económica, 2014, 615-733 (= 2014b).

Hummel, Martin, Adjectives with adverbial functions in Romance, in: Hummel, Martin/Valera, Salvador (edd.), Adjective Adverb Interfaces in Romance, Amsterdam/Philadelphia, Benjamins, 2017, 13-46.

Hummel, Martin, Éléments d'une diachronie grammaticographique et normative de l'adverbe français accompagnés de trois méthodes pour mesurer l'effet du discours normatif sur l'usage, Romanische Forschungen 130 (2018), 3-35.

Hummel, Martin, The third way: prepositional adverbials in the diachrony of Romance, part 1 , Romanische Forschungen 131 (2019), 145-185 (= 2019a).

Hummel, Martin, The third way: prepositional adverbials in the diachrony of Romance, second and last part, Romanische Forschungen 131 (2019), 295-327 (= 2019b).

Hummel, Martin/Valera, Salvador (edd.), Adjective Adverb Interfaces in Romance, Amsterdam/ Philadelphia, Benjamins, 2017.

Ilari, Rodolfo, et al., Considerações sobre a posição dos advérbios, in: Teixeira de Castilho, Ataliba (ed.), Gramática do português falado: A ordem, vol. 1, São Paulo, UNICAMP, 1990, 53-121.

Ilari, Rodolfo, et al., Sobre os advérbios aspectuais, in: Texeira de Castilho, Ataliba (ed.), Gramática do português falado: Níveis de análise lingüística, vol. 2, Campinas, UNICAMP, 2003, 139-182.

Insausti, Catalina, Procesos de gramaticalización en la formación de locuciones preposicionales: "en cabeza de" y “a cabeza de", Logos. Revista de lingüística, filosofía y literatura 28 (2018), 206-220, DOI: <dx.doi.org/10.15443/RL2816>.

Jiménez Juliá, Tomás Eduardo, Notas sobre locuciones y construcciones sintácticas, Cuadernos AISPI: Estudios de lenguas y literaturas hispánicas 10 (2017), 91-112.

Jorge, Guilhermina, Algumas reflexões em torno das expressões idiomáticas enquanto elementos que participam na construção de uma identidade cultural, Polifonia 4 (2001), 215-222.

Jørgensen, Annette Myre, “En plan" used as a hedge in Spanish teenage language, in: Stenström, Anna-Brita/Jørgensen, Annette Myre (edd.), Youngspeak in a Multilingual Perspective, Amsterdam/Philadelphia, Benjamins, 2009, 95-115.

Kazumi, Koike, Valores funcionales de las locuciones prepositivas en español, Onomázein: Revista de lingüística, filología y traducción de la Pontificia Universidad Católica de Chile 2 (1997), 151-179. 
Klein, Hans-Wilhelm, “Courageusement - avec courage”. Observations sur la structure de l'adverbe français, Travaux de linguistique et de littérature 11 (1973), 407-414.

Kloss, Heinz, “Abstand languages" and "Ausbau languages", Anthropological linguistics 9 (1967), 29-41.

Kloss, Heinz, Die Entwicklung neuer germanischer Kultursprachen seit 1800, Düsseldorf, Schwann, 1978.

Kofler, Michaela, Der Gebrauch der Modaladverbien in drei französischsprachigen Romanen von Andreï Makine, Philippe Djian und Alphonse Boudard, master thesis, Karl-Franzens-Universität Graz, 2007.

Kühner, Raphael/Holzweissig, Friedrich, Ausführliche Grammatik der lateinischen Sprache, Erster Teil: Elementar-, Formen- und Wortlehre, Hannover, Hahnsche Buchhandlung, 1986 [1912].

La Touche, Pierre de, L'Art de bien parler françois, 2 vol., Genève, Slatkine, 1973 [1696].

Lafaye, M[aître] [=Pierre-Benjamin], Dictionnaire des synonymes de la langue française, Paris, Hachette, ${ }^{2} 1861$.

Lange, Wolf Dieter, Philologische Studien zur Latinität westhispanischer Privaturkunden des 9.12. Jahrhunderts, Leiden/Köln, Brill, 1966.

Lapesa, Rafael, "Alma" y "ánima" en el "Diccionario histórico de la lengua española": su fraseología, in: id. (ed.), Léxico e historia. II. Diccionarios, Madrid, Istmo, 1992 [1981], 79-86.

Lausberg, Heinrich, Romanische Sprachwissenschaft, vol. 3: Formenlehre, Berlin/New York, De Gruyter, ${ }^{2} 1972$.

Lavale-Ortiz, Ruth Maria, A cognitive approach to the grammaticalization of the epistemic marker “fijo", in: Fernández Jaén, Jorge/Provencio Garrigós, Herminia (edd.), Historical Linguistics. Current Theories and Applications, Amsterdam/Philadelphia, Benjamins, in press.

Le Goffic, Pierre, Grammaire de la phrase française, Paris, Hachette, 1993.

Ledgeway, Adam, Italian, Tuscan, and Corsican, in: id./Maiden, Martin (edd.), The Oxford Guide to the Romance Languages, Oxford, Oxford University Press, 206-227 (= 2016a).

Ledgeway, Adam, The dialects of southern Italy, in: id./Maiden, Martin (edd.), The Oxford Guide to the Romance Languages, Oxford, Oxford University Press, 2016, 246-279 (= 2016b).

Ledgeway, Adam/Maiden, Martin (edd.), The Oxford Guide to the Romance Languages, Oxford, Oxford University Press, 2016.

Leumann, Manu/Szantyr, Anton/Hofman, Johann, Lateinische Grammatik, Syntax und Stilistik, vol. 2, München, Beck, 1972 [1907].

Lodge, Gonzalez, Lexikon Plautinum, Leipzig, Teubner, 1924.

Löfstedt, Einar, Philologischer Kommentar zur Peregrinatio Aetheriae, Uppsala, Almqvist/Wiksell, 1911.

Lonzi, Lidia, VII. Il sintagma avverbiale, in: Renzi, Lorenzo/Salvi, Giampaolo/Cardinaletti, Anna (edd.), Grande grammatica italiana di consultazione: I sintagmi verbale, aggettivale, avverbiale. La subordinazione, vol. 2, Bologna, il Mulino, 2001, 341-412.

López García, Ángel/Morant-Marco, Ricard, L'adverbi, in: Solà Cortassa, Joan/Lloret, MariaRosa/Mascaró, Joan/Pérez Saldanya, Manuel (edd.), Gramática del català contemporani (gramatica del catala contempor), vol. 2, Barcelona, Empuries, 2008, 1797-1852.

Loporcaro, Michele/Paciaroni, Tania, The dialects of Central Italy, in: Ledgeway, Adam/Maiden, Martin (edd.), The Oxford Guide to the Romance Languages, Oxford, Oxford University Press, 2016, 228-245.

Lorente Casafont, Marcè, Altres elements lèxics, in: Solà Cortassa, Joan/Lloret, Maria-Rosa/Mascaró, Joan/Pérez Saldanya, Manuel (edd.), Gramàtica del català contemporani (gramatica del catala contempor), vol. 1, Barcelona, Empuries, 2008, 831-888. 
LRL 4 = Holtus, Günter/Metzeltin, Michael/Schmitt, Christian (edd.), Lexikon der Romanistischen Linguistik (LRL), vol. 4: Italienisch, Korsisch, Sardisch, Tübingen, Niemeyer, 1988.

Lubello, Sergio (ed.), Manuale di linguistica italiana, Berlin/Boston, De Gruyter, 2016.

Luque Toro, Luis, Diccionario contextual de locuciones preposicionales, Granada, Granada Lingvistica, 2009.

Macedo Rocha, Carlos Alberto de/Macedo Rocha, Carlos Eduardo Penna de, Dicionário de locuções e expressões da língua portuguesa, Rio de Janeiro, Lexikon, 2011.

Maiden, Martin/Robustelli, Cecilia, Reference Grammar of Modern Italian, London, Arnold, 2000.

Marcos Sánchez, María de las Mercedes, A propósito del marcador "por lo visto”, in: Santos Río, Luis (ed.), Palabras, norma, discurso. En memoria de Fernando Lázaro Carreter, Salamanca, Universidad, 2005, 777-786.

Martelotta, Mário Eduardo, Advérbio - conceito e tendências de ordenação, in: Oliveira, Mariangela Rios de/Cezario, Maria Maura (edd.), Adverbiais. Aspectos gramaticais e pressões discursivas, Niterói, UFF, 2012, 13-96.

Martí Mestre, Joaquim, Diccionari històric del valencià col·loquial, València, Universitat de València, 2006.

Martí Mestre, Joaquim, Diccionari de fraseología (segles XVII-XX), València, PUV/PUA/AVL/Institut Alfons el Magnànim, 2017.

Martín Zorraquino, María Antonia, Reflexiones sobre el estudio de los marcadores del discurso desde la perspectiva diacrónica, in: Echenique Elizondo, María Teresa/Sánchez Méndez, Juan Pedro (edd.), Actas del V Congreso Internacional de Historia de la Lengua Española, Madrid, Arco Libros, 2002, 285-292.

Martines Peres, Vincent, Materials per a l'anàlisi multilingüe i contrastiva de locucions, col·locacions i fraseología. Un escandall quant a Ausiàs March i Tirant lo Blanch, Caplletra. Revista internacional de filologia 40 (2007), 153-191, DOI: <10.7203/caplletra.40.4845>.

Martínez López, Juan Antonio, La adverbialización modal con la preposición “a”, Lingüística española actual 21 (1999), 67-98.

Martínez López, Juan Antonio, Estudio diacrónico de las locuciones adverbiales con la preposición "en", Cauce: revista de filología y su didáctica 30 (2007), 207-221.

Martínez López, Juan Antonio/Jørgensen, Annette Myre, La adverbialización con la preposición “de": patrones y frecuencias, Dialogía: revista de lingüistica, literatura y cultura 7 (2013), 4-22.

Meléndez Quero, Carlos, La locución adverbial "por suerte”: propiedades sintáctico-distribucionales, instrucciones discursivas e intenciones argumentativas, in: Casanova, Emili/Calvo Rigual, Cesáreo (edd.), Actas del XXVI Congreso Internacional de Lingüística y de Filología Románicas, vol. 6, Berlin, De Gruyter, 2013, 595-606.

Méndez Orense, María, Valores pragmático-discursivos de la construcción lingüística "en plan". ¿Formación de un nuevo marcador?, Philologia hispalensis 30 (2016), 123-144, DOI: $<10.12795 /$ PH.2016.i30.07〉.

Meyer-Lübke, Wilhelm, Grammatik der romanischen Sprachen, vol. 3: Romanische Syntax, Hildesheim/New York, Olms, 1972 [1899].

Mihai, Cornelia, Valoarea adverbială a adjectivelor în limba română contemporană, in: Studii şi cercetări lingvistice 14:2 (1963), 209-218.

Mîrzea-Vasile, Carmen, Eterogenitatea adverbului românesc: tipologie şi descriere, Bucureşti, Editura Universităţii din Bucureşti, 2012.

Móia, Telmo/Alves, Ana Teresa, Differences between European and Brazilian Portuguese in the use of temporal adverbials, Journal of Portuguese linguistics 3:1 (2004), 37-67, DOI: <http://doi.org/10.5334/jpl.18>. 
Moll Casanovas, Francisco, Gramática histórica catalana, Madrid, Gredos, 1952.

Montoro del Arco, Esteban Tomás, Teoría fraseológica de las locuciones particulares. Las locuciones prepositivas, conjuntivas y marcadoras en español, Frankfurt am Main, Lang, 2006.

Montoro del Arco, Esteban Tomás, Palabras, sintagmas y locuciones: los límites de las categorías prepositiva y conjuntiva, Per Abbat: boletín filológico de actualización académica y didáctica 5 (2008), 63-76.

Mora, Javier, ¿Preposición tras preposición en expresiones adverbiales del español del México?, in: García Bravo, Eva/Fernández Alcaide, Joaquín (edd.), El español de América: morfosintaxis histórica y variación, Valencia, Tirant lo Blanch, in press.

Náñez Fernández, Emilio, La locución prepositiva en el lenguaje administrativo, Boletín de la Real Academia Española 71 (1991), 383-396.

Náñez Fernández, Emilio, Diccionario de construcciones sintácticas del español. Preposiciones, Madrid, Universidad Autónoma de Madrid, 2001.

Neves, Maria Helena Moura, Gramática de usos do português, São Paulo, UNESP, 2000.

Neves, Maria Helena Moura, Os advérbios circunstanciais (de lugar e de tempo), in: Ilari, Rodolfo (ed.), Gramática do português falado. Níveis de análise lingüística, vol. 2, São Paulo, Unicamp, 2002, 139-182.

Neves, Orlando, Dicionário das origens das frases feitas, Porto, Lello \& Irmão, 1992.

Nica, Dumitru, Teoria părţilor de vorbire. Aplicaţii la adverb, Iaşi, Editura Junimea, 1988.

Nilsson-Ehle, Hans, Les adverbes en “-ment” compléments d'un verbe, Lund/Copenhague, Gleerup/Munksgaard, 1941.

Nøjgaard, Morten, Les adverbes français, 3 vol., Copenhague, Munksgaard, 1992-1995.

Nyrop, Christophe, Grammaire historique de la langue française, 6 vol., Genève, Slatkine Reprints, 1979 [1914-1960].

Ocampo, Francisco, Movement towards discourse is not grammaticalization. The evolution of "claro" from adjective to discourse particle in spoken Spanish, in: Sagarra, Nuria/Toribio Almeida, Jacqueline (edd.), Selected Proceedings of the 9th Hispanic Linguistics Symposium, Somerville, Cascadilla Proceedings Project, 2006, 308-319 (retrieved from: <http:// www.lingref.com/cpp/hls/9/paper1388.pdf> [last access: 20/05/2019]) $(=2006 \mathrm{a})$.

Ocampo, Francisco, La evolución de "bueno" de adjetivo a partícula discursiva. Un proceso de discursivización, Oralia: Análisis del discurso oral 9 (2006), 231-257 (= 2006b).

Octavio de Toledo y Huerta, Álvaro, Los relacionantes locativos en la historia del español, Berlin/ Boston, De Gruyter, 2016.

Ojeda Socorro, Ascensión María Lourdes, Estudio de las frases prepositivas en el habla culta de Sevilla, tesis doctoral, Sevilla, Universidad de Sevilla, 2014.

Oliveira, Mariangela Rios/Cezario, Maria Maura (edd.), Adverbiais. Aspectos gramaticais e pressões discursivas, Niterói, Editora da Universidade Federal Fluminense, 2012.

Oliveira, Mariangela Rios/Cezario, Maria Maura/Martelotta, Mário Eduardo/Furtado da Cunha, Maria Angélica, Adverbiais em língua portuguesa. Semântica e sintaxe em perspectiva funcional, Revista do GEL 8:2 (2013), 7-39.

Ortega Ojeda, Gonzalo Damián/González Aguiar, María Isabel, Fraseología histórica y dialectología: la perspectiva del español de Canarias, in: Echenique Elizondo, María Teresa/Martínez Alcalde, María José/Pla Colomer, Francisco P., La fraseología a través de la historia de la lengua española y su historiografía, Valencia, Tirant humanidades, 2017, 15-47.

Ortiz Ciscomani, Rosa María, Locuciones adverbiales con "a" y base léxica en "-as", in: Company Company, Concepción (ed.), Sintaxis histórica de la lengua española. Tercera 
parte: Adverbios, preposiciones y conjunciones. Relaciones interoracionales, tomo 1, México, Universidad Nacional Autónoma de México-Fondo de Cultura Económica, 2014, 1117-1192.

Ortiz Ciscomani, Rosa María, From adjective to adverbial modal locutions in Spanish, in: Hummel, Martin/Valera, Salvador (edd.), Adjective Adverb Interfaces in Romance, Amsterdam/Philadelphia, Benjamins, 2017, 305-327, DOI: 〈https://doi.org/10.1075/la.242.12ort>.

Oudin, Antoine, Grammaire françoise rapportée au langage du temps, Genève, Slatkine Reprints, $1972[1632 / 1640]$.

Palau i Martí, Ferran/Fundació, Jaume I., El problema de les preposicions "per" $i$ “per a”, Barcelona, Barcino, 1986.

Palet Plaja, María Teresa, Un problema de lingüística contrastiva: las preposiciones en español y catalán, Revista española de lingüística 17 (1987), 69-84.

Palma, Cristina, Expressões fixas adverbiais. Descrição léxico-sintáctica e subsídios para um estudo contrastivo Português-Espanhol, dissertação de mestrado, Faro, Universidade do Algarve, 2009.

Palsgrave, John, Lesclarcissement de la langue françoyse, Genève, Slatkine Reprints, 1972 [1530].

Paulino Machado, Natalia Ilse, As locuções adverbiais temporais e aspectuais nos séculos XVIII $e$ XIX do português: um estudo da ordem, Lingüística 29:1 (2013), 59-80.

Pavón Lucero, Mará Victoria, Clases de partículas: preposición, conjunción y adverbio, in: Demonte, Violeta/Bosque, Ignacio (edd.), Gramática descriptiva de la lengua española, vol. 1, Madrid, Espasa-Calpe, 1999, 565-656.

Pavón Lucero, María Victoria, Locuciones del tipo "a fin de": ¿preposicionales o conjuntivas?, Español actual. Revista de español vivo 99 (2013), 121-128.

Pecoraro, Walter/Pisacane, Chiara, L'avverbio, Bologna, Zanichelli, 1984.

Penadés Martínez, Inmaculada, Diccionario de locuciones adverbiales para la enseñanza del español, Madrid, Arco Libros, 2005.

Penadés Martínez, Inmaculada, Gramática y semántica de las locuciones, Alcalá de Henares, Universidad de Alcalá, 2012.

Perera i Parramon, Joan, Contribució a l'estudi de les preposicions en el "Tirant lo Blanc" (primera part), Llengua i Literatura 1 (1986), 51-109.

Perera i Parramon, Joan, Contribució a l'estudi de les preposicions en el "Tirant lo Blanc" (segona part), Llengua i Literatura 2 (1987), 19-66.

Pérez-Salazar, Carmela, “A lo mejor, lo mismo". De la comparación y la identidad a la modalización epistémica, in: Garcés Gómez, María del Pilar (ed.), Los adverbios con función discursiva: procesos de formación y evolución, Madrid/Frankfurt, Iberoamericana/Vervuert, 2013, 201-238.

Piunno, Valentina, Sintagmi preposizionali con funzione aggettivale o avverbiale, München, LINCOM, 2018.

Pla Colomer, Francisco Pedro/Vicente Llavata, Santiago, Aproximación a una fraseología contrastiva en los textos peninsulares de materia troyana: el Libro de Alexandre, la Historia troyana polimétrica y la Crónica troyana de Juan Fernández de Heredia, in: Echenique Elizondo, María Teresa/Martínez Alcalde, María José/Pla Colomer, Francisco P., La fraseología a través de la historia de la lengua española y su historiografía, Valencia, Tirant humanidades, 2017, 113-153.

Plattner, Philipp, Das Nomen und der Gebrauch des Artikels in der französischen Sprache, Karlsruhe, Bielefeld, 1905.

Plattner, Philipp, Präpositionen und Adverbien, Freiburg, Bielefeld, 1907. 
Pons Bordería, Salvador/Ruiz Gurillo, Leonor, “De todas maneras”: fijación formal y pragmática, Revista de filología española 81 (2001), 317-351.

Porcel Bueno, David, Variación y fijeza en la fraseología castellana medieval. Locuciones prepositivas complejas en la prosa sapiencial castellana (Siglos XIII-XV), tesis doctoral, Valencia, Universitat de València, 2015.

Porcel Bueno, David, Los procesos de derivación locucional en el continuum discursivo de la literatua medieval de castigos, Memorabilia: boletín de literatura sapiencial 18 (2016), 235250 (= 2016a).

Porcel Bueno, David, Formas locucionales prepositivas en los libros y colecciones de sentencias castellanas del siglo XIII, in: Echenique Elizondo, María Teresa/Martínez Alcalde, María José/Sánchez Méndez, Juan Pedro/Pla Colomer, Francisco P. (edd.), Fraseología española. Diacronía y codificación, Madrid, CSIC, 2016, 225-236 (= 2016b).

Porcel Bueno, David, Hacia una nueva categorización de las unidades fraseológicas desde una perspectiva histórica: locuciones prepositivas y formas locucionales prepositivas en el castellano del siglo XIV, E-Spania. Revue interdisciplinaire d'études hispaniques médiévales et modernes 29 (2017), 23-35, DOI : <10.4000/e-spania.27657> (= 2017a).

Porcel Bueno, David, Unidades fraseológicas, tradiciones discursivas y géneros textuales en diacronía, in: Echenique Elizondo, María Teresa/Martínez Alcalde, María José/Pla Colomer, Francisco P., La fraseología a través de la historia de la lengua española y su historiografía, Valencia, Tirant humanidades, 2017, 173-194 (= 2017b).

Prandi, Michele, Le regole e le scelte. Introduzione alla grammatica italiana, Turin, UTET Università, 2006.

Quilis Merín, Mercedes, De Nebrija a Franciosini (1495?-1620): presencia y consolidación de las locuciones adverbiales en la lexicografía histórica del español, in: Company Company, Concepción/Moreno de Alba, José G. (edd.), Actas del VII Congreso Internacional de Historia de la Lengua Española, vol. 1, Madrid, Arco Libro, 2008, 1017-1034.

Quilis Merín, Mercedes, Fijación y variación en el uso de las locuciones prepositivas en la lexicografía del Siglo de Oro. El "Tesoro de la Lengua Castellana o Española" (1611) de Sebastián de Covarrubias, in: Echenique Elizondo, María Teresa/Martínez Alcalde, María José/Sánchez Méndez, Juan Pedro/Pla Colomer, Francisco P. (edd.), Fraseología española. Diacronía y codificación, Madrid, CSIC, 2016, 257-272.

Rainer, Franz, Derivational morphology, in: Ledgeway, Adam/Maiden, Martin (edd.), The Oxford Guide to the Romance Languages, Oxford, Oxford University Press, 2016, 513-523.

Ramat, Paolo/Ricca, Davide, Sentence adverbs in the languages of Europe, in: Auwera, Johan van der (ed.), Adverbial Constructions in the Languages of Europe, Berlin/New York, Mouton de Gruyter, 1998, 187-275.

Raposo, Eduardo Buzaglo Paiva, et al., Gramática do português, vol. 2, Lisboa, Gulbenkian, 2013.

RAE 2009 = Real Academia Española, Nueva gramática de la lengua española, Madrid, EspasaCalpe/Asociación de Academias de la Lengua Española, 2009.

Renzi, Lorenzo, Storia interna dell'italiano: morfosintassi e sintassi / Interne Sprachgeschichte des Italienischen: Morphosyntax und Syntax, in: Ernst, Gerhard/Gleßgen, Martin-Dietrich/ Schmitt, Christian/Schweickard, Wolfgang (edd.), Romanische Sprachgeschichte / Histoire linguistique de la Romania. Ein internationales Handbuch zur Geschichte der romanischen Sprachen / Manuel historique d'histoire linguistique de la Romania, vol. 3, Berlin/New York, De Gruyter, 2008, 2830-2846. 
Renzi, Lorenzo/Salvi, Giampaolo/Cardinaletti, Anna (edd.), Grande grammatica italiana di consultazione, vol. 2: I sintagmi verbale, aggettivale, avverbiale. La subordinazione, Bologna, il Mulino, 2001.

Rheinfelder, Hans, Altfranzösische Grammatik, vol. 2: Formenlehre, München, Hueber, 1967.

Ricós Vidal, Amparo, Las unidades fraseológicas en los textos hispanos y lusos del siglo XVI: el ejemplo de Gil Vicente, in: Girón Alconchel, José Luis/Bustos Tovar, José Jesús de (edd.), Actas del VI Congreso Internacional de Historia de la Lengua española, Madrid, Arco Libros, 2006, 2039-2050.

Ricós Vidal, Amparo, De locuciones coordinadas a sintagmas complejos. A propósito de "a diestro y siniestro", "a tuerto o a derecho", "a tontas y a locas", in: Olza Moreno, Inés/Casado Velarde, Manuel/González Ruiz, Ramón (edd.), Actas del XXXVII Simposio Internacional de la SEL, Pamplona, Universidad de Navarra, 2008, 707-717 (= 2008a).

Ricós Vidal, Amparo, Locuciones adverbiales con preposición "a" y adjetivo en el español y el portugués del siglo XVI. Estudio histórico, in: Company Company, Concepción/Moreno de Alba, José (edd.), Actas del VII Congreso Internacional de Historia de la Lengua Española, vol. 1, Madrid, Arco Libros, 2008, 1035-1054 (= 2008b).

Ricós Vidal, Amparo, As locuções adverbiais nos dicionários trilingues seiscentistas portugueses, in: Rebelo, Helena (ed.), Lusofonia tempo de reciprocidades: Actas IX Congresso da Associação Internacional de Lusitanistas, 2011, 29-40.

Ricós Vidal, Amparo, “A reculas, a hotas, a sabiendas, a la deshilada, a la callada, a la sorda”: más sobre locuciones adverbiales, in: García Valle, Adela/Ricós Vidal, Amparo/Sánchez Méndez, Juan Pedro (ed.), Fablar bien e tan mesurado, Valencia, Tirant Humanidades, 2012, 63-86.

Ricós Vidal, Amparo, El origen de algunas locuciones prepositivas en gallego y portugués: análisis de las crónicas medievales, in: Echenique Elizondo, María Teresa/Martínez Alcalde, María José/Sánchez Méndez, Juan Pedro/Pla Colomer, Francisco P. (edd.), Fraseología española. Diacronía y codificación, Madrid, CSIC, 2016, 237-256.

Riegel, Martin/Pellat, Jean-Christophe/Rioul, René, Grammaire méthodique du français, Paris, Presses Universitaires de France, 2013.

Risicato, Antonino, Lingua parlata e lingua d'arte in Ennio, Messina, La Editrice Universitaria, 1950.

Robert, C.-M., Questions de grammaire et de langue françaises, Amsterdam, Brinkmann, 1886.

Rodríguez Lage, Laura, Análisis de los usos de "en plan" en un corpus de español de Galicia, in: Santos Rovira, José María (ed.), Variación lingüística e identidad en el mundo hispanohablante, Lugo, Axac Humanidades, 2017, 75-89.

Rodríguez Molina, Javier, Adverbios y locuciones adverbiales de manera, in: Company Company, Concepción (ed.), Sintaxis histórica de la lengua española. Tercera parte: Adverbios, preposiciones y conjunciones. Relaciones interoracionales, tomo 1, México, Universidad Nacional Autónoma de México-Fondo de Cultura Económica, 2014, 733-938.

Rohlfs, Gerhard, Grammatica storica della lingua italiana e dei suoi dialetti, vol. 3: Sintassi e formazione delle parole, Torino, Einaudi, 1969.

Rolli, Paolo, D'avverbj, particelle, preposizioni e di frasi avverbiali libretto. Utilissimo a gl'Inglesi amatory della Lingua Italiana, London, Chrichley, 1741.

Ruíz Gurillo, Leonor, Relaciones categoriales de las locuciones adverbiales, Contextos 15:29-30 (1997), 19-32.

Ruíz Gurillo, Leonor, Compuestos, colocaciones, locuciones: intento de delimitación, in: González Pereira, Miguel/Souto Gómez, Monserrat/Veiga Rodríguez, Alexandre (edd.), Léxico y gra- 
mática: [Selección de ponencias e comunicacións presentadas no Congreso Internacional de Lingüística “Léxico \& Gramática” elebrado na Facultade de Humanidades de Lugo do 25 ó 28 de setembro de 2000], s.l., s.e., 2002, 327-339.

Salvi, Giampaolo, Word order, in: Ledgeway, Adam/Maiden, Martin (edd.), The Oxford Guide to the Romance Languages, Oxford, Oxford University Press, 2016, 997-1012.

Salvi, Giampaolo/Renzi, Lorenzo (edd.), Grammatica dell'italiano antico, 2 vol., Bologna, il Mulino, 2010.

Sancho Cremades, Pelegrí, Les preposicions en català, València, Universitat de València, 1994.

Sancho Cremades, Pelegrí, La categoria preposicional, València, Universitat de València, 1995.

Sancho Cremades, Pelegrí, La preposició i el sintagma preposicional, in: Cortassa Solà, Joan (ed.), Gramàtica del català contemporani, vol. 2, Barcelona, Empuries, 2008, 1689-1795.

Santos Río, Luis, Sobre el tratamiento de la locución prepositiva en las obras de la Real Academia, in: Maquieira Rodríguez, Marina/Martínez Gavilán, María Dolores/Villayandre Llamaz ares, Milka (edd.), Actas del II Congreso Internacional de la Sociedad Española de Historiografía Lingüística, Madrid, Arco Libros, 2001, 859-874.

Santos Río, Luis, Clases de locuciones prepositivas, in: Sánchez Miret, Fernando (ed.), Actas del XXIII Congreso Internacional de Lingüística y Filología Románica, vol. 2, Tübingen, Niemeyer, 2003, 331-362 (= 2003a).

Santos Río, Luis, Diccionario de partículas, Salamanca, Luso-Española de Ediciones, 2003 $(=2003 \mathrm{~b})$.

Santos Río, Luis, Locuciones y pseudolocuciones prepositivas: los esquemas de "Líneas generales", Salamanca, Imprenta Salamanca, 2004.

Santos, António, Novos dicionários de expressões idiomáticas, Lisboa, Sá da Costa, 1990.

Satorre Grau, Francisco Javier, Las locuciones adverbiales en la lexicografía hispanolatina del Siglo de Oro, in: Company Company, Concepción/Moreno de Alba, José (edd.), Actas del VII Congreso Internacional de Historia de la Lengua Española, vol. 1, Madrid, Arco Libros, 2008, 1125-1136.

Satorre Grau, Francisco Javier, Grados de gramaticalización en las locuciones prepositivas del español, in: Echenique Elizondo, María Teresa/Martínez Alcalde, María José/Pla Colomer, Francisco P., La fraseología a través de la historia de la lengua española y su historiografía, Valencia, Tirant humanidades, 2017, 197-211.

Säuborg, Torsten, Étude sur le rôle de la préposition “de" dans les expressions de lieu relatives en latin vulgaire et en ancien gallo-roman, Uppsala, Lundequistska Bokhandeln, 1941.

Sauer, Karl Marquard, Neue italienische Conversations-Grammatik, Heidelberg, Groos, ${ }^{5} 1874$.

Schnedecker, Catherine, “En tout" et "au total": des adverbiaux jumeaux, in: Birkelund, Merete/ Mosegaard Hansen, Maj-Britt/Norén, Coco (edd.), L'énonciation dans tous ses états, Bern et al., Lang, 2008, 645-668.

Seco, Manuel/Andrés, Olimpia/Ramos, Gabino, Diccionario fraseológico documentado del español actual. Locuciones y modismos españoles, Madrid, Aguilar, 2005.

Serianni, Luca, Grammatica italiana. Italiano comune e lengua letteraria, Torino, UTET, 1988.

Silvestri, Giuseppina, Adverb agreement in the dialects of the "Lausberg Area", in: Hummel, Martin/Valera, Salvador (edd.), Adjective Adverb Interfaces in Romance, Amsterdam/Philadelphia, Benjamins, 2017, 173-204, DOI: 〈https://doi.org/10.1075/la.242.07sil>.

Simões, Guilherme Augusto, Dicionário de expressões populares portuguesas, Lisboa, Publicações Dom Quixote, 1993.

Skelton, Robert B., La locución adverbial “de en balde” y la fusión fonética, Boletín de la Real Academia Española 51 (1971), 459-474. 
Skytte, Gunver, Flexionslehre / La flessione, in: Holtus, Günter/Metzeltin, Michael/Schmitt, Christian (edd.), Lexikon der Romanistischen Linguistik (LRL), vol. 4: Italienisch, Korsisch, Sardisch, Tübingen, Niemeyer, 1988, 39-51.

Slager, Emile, Pequeño diccionario de construcciones preposicionales, Madrid, Visor, 1997.

Soares, Bruna das Graças, Ordenação de locuções adverbiais temporais iniciadas pela preposição "em" (e contrações) em textos jornalísticos, dissertação de mestrado, Rio de Janeiro, Universidade Federal do Rio de Janeiro, 2012.

Solà Cortassa, Joan/Lloret, Maria-Rosa/Mascaró, Joan/Pérez Saldanya, Manuel (ed.), Gramàtica del català contemporani, 3 vol., Barcelona, Empuries, 2008.

SOR = Pană Dindelegan, Gabriela (ed.), The Syntax of Old Romanian, Oxford, Oxford University Press, 2016.

Suárez Hernández, Ariana, La evolución y representación en un diccionario histórico de los adverbios "quizá", “tal vez", “a lo mejor”, "acaso”, in: Garcés Gómez, María del Pilar (ed.), Lexicografía teórica y aplicada, A Coruña, Universidade da Coruña, 2014, 367-378.

Tagliavini, Carlo, Le origini delle lingue neolatine. Introduzione alla filologia romanza, Bologna, Pàtron, ${ }^{3} 1959$.

$\mathrm{TLL}=$ Thesaurus linguae latinae, Leipzig/München/Berlin, Teubner/Saur/De Gruyter, 1900ss.

Tobler, Adolf/Lommatzsch, Erhard, Altfranzösisches Wörterbuch, 11 vol., Berlin/Wiesbaden/ Stuttgart, Weidmann/Steiner, 1925-2002.

Togeby, Knud, Grammaire française, edd. Berg, Magnus/Merad, Ghani/Spang-Hanssen, Ebbe, 5 vol., Copenhague, Akademisk Forlag, 1982-1985.

Ueda, Hiroto, Frases prepositivas en español, Tokyodaigaku Kyooyoogakubu Kiyoo 22 (1990), 9-33.

Väänänen, Veikko, Introducción al latín vulgar, Madrid, Gredos, 1995 [1967].

Vanelli, Laura, Morphosyntax / Morfosintassi, in: Holtus, Günter/Metzeltin, Michael/Schmitt, Christian (edd.), Lexikon der Romanistischen Linguistik (LRL), vol. 4: Italienisch, Korsisch, Sardisch, Tübingen, Niemeyer, 1988, 94-112.

Vasile, Carmen, Adverbul românesc între continuitate latină, specific balcanic şi evoluţie internă, Bucureşti, Editura Muzeului Naţional al Literaturii Române, 2013.

Vázquez Cuesta, Pilar/Mendes da Luz, Maria Albertina, Gramática portuguesa, Madrid, Gredos, 1971.

Veneroni, Giovanni, Herrn von Veneroni italiänisch-frantzösisch- und teutsche Grammatica oder Sprach-Meister. So ordentlich eingerichtet/daß man darinnen An Grammaticalischen Grund-Regeln/füglichen Exempeln/zierlichen Redens-Arten/bequemen Gesprächen/sinnreichen Sprüchwörtern/anmutigen Historien/poßirlichen Begebenheiten und Stand-gebührlichen Titulaturen/alles kürzlich beysammen findet, Frankfurt/Leipzig, Johann Philipp Andreä, ${ }^{11} 1713$.

Vernet i Anguera, Roser, Aproximació a un estudi de les unitats lingüístiques estereotipades a Primera historia d'Esther, Llengua \& literatura 10 (1999), 197-242.

Vicente Llavata, Santiago, Sobre el valor de la locución adverbial "a tiempo" en los romances hispánicos, in: Tomás Montoro del Arco, Esteban/Sánchez García, Francisco José/López Vallejo, María Ángeles (edd.), Nuevas perspectivas en torno a la diacronía lingüística. Actas del IV Congreso Nacional de la Asociación de Jóvenes Investigadores de Historiografía e Historia de la Lengua, Granada, Universidad de Granada, 2008, 519-532 (= 2008a).

Vicente Llavata, Santiago, La locución adverbial "a temps / a tiempo" en el marco del humanismo peninsular, Paremia 17 (2008), 121-130 (= 2008b). 
Vicente Llavata, Santiago, Estudio de las locuciones en la obra literaria de Don Îñigo López de Mendoza (Marqués de Santillana). Hacia una fraseología histórica del español, Valencia, Universitat de València, 2011.

Vicente Llavata, Santiago, Notas de Fraseología hispánica medieval. A propósito de la impronta catalano-aragonesa en la obra literaria de don Íñigo López de Mendoza, in: Casanova, Emili/Calvo Rigual, Cesáreo (edd.), Actas del XXVI Congreso Internacional de Lingüística y de Filología Románicas, vol. 4, Berlin, De Gruyter, 2013, 431-444.

Vilaró i Casalinas, Francesc, La funció de "en funció de", Revista de llengua y dret 10 (1987), 75-82. Vilela, Mário, As expressões idiomáticas na língua e no discurso, in: Duarte, Isabel Margarida/ Barbosa, Joaquim/Matos, Sergio/Hüsgen, Thomas (edd.), Actas do Encontro Comemorativo dos 25 anos do Centro de Linguística da Universidade do Porto, vol. 1, Porto, Centro de Linguística da Universidade do Porto, 2002, 159-189.

Villar Díaz, María Belén, La evolución de los adverbios y locuciones adverbiales de modalidad epistémica, in: Garcés Gómez, María del Pilar (ed.), Los adverbios con función discursiva. Procesos de formación y evolución, Madrid/Frankfurt am Main, Iberoamericana/Vervuert, 2013, 157-200.

Wagner, Robert León/Pinchon, Jacqueline, Grammaire du français classique et moderne, Paris, Hachette, 1987.

Waluch de la Torre, Edyta, Secuencias preposicionales en español peninsular: introducción al estudio, Itinerarios: revista de estudios lingüísticos, literarios, históricos y antropológicos 16 (2012), 237-253.

Wartburg, Walther von/Zumthor, Paul, Précis de syntaxe du français contemporain, Berne, Francke, 1989.

Wasa, Atsuko, “A lo mejor” y el subjuntivo, Hispania 85 (2002), 131-136.

Zauner, Adolf, Romanische Sprachwissenschaft: Wortlehre II und Syntax, vol. 2, Berlin/Leipzig, De Gruyter, 1926.

Zink, Gaston, Morphologie du français médiéval, Paris, Presses Universitaires de France, 2000. Zuluaga, Alberto, Introducción al estudio de las expresiones fijas, Tübingen, Niemeyer, 1980. 